\title{
Historical and Epistemological Perspectives on What Horizontal Gene Transfer Mechanisms Contribute to Our Understanding of Evolution
}

\author{
Nathalie Gontier
}

\begin{abstract}
Since the 1990s, results coming in from molecular phylogenetics necessitate us to recognize that Horizontal Gene Transfer (HGT) occurs massively across all three domains of life. Nonetheless, many of the mechanisms whereby genes can become transferred laterally have been known from the early twentieth century onward. The temporal discrepancy between the first historical observations of the processes, and the rather recent general acceptance of the documented data, poses an interesting epistemological conundrum: Why have incoming results on HGT been widely neglected by the general evolutionary community and what causes for a more favorable reception today? Five reasons are given: (1) HGT was first observed in the biomedical sciences and these sciences did not endorse an evolutionary epistemic stance because of the ontogeny/phylogeny divide adhered to by the founders of the Modern Synthesis. (2) Those who did entertain an evolutionary outlook associated research on HGT with a symbiotic epistemic framework. (3) That HGT occurs across all three domains of life was demonstrated by modern techniques developed in molecular biology, a field that itself awaits full integration into the general evolutionary synthesis. (4) Molecular phylogenetic studies of prokaryote evolution were originally associated with exobiology and abiogenesis, and both fields developed outside the framework provided by the Modern Synthesis. (5) Because HGT brings forth a pattern of reticulation, it contrasts the standard idea that evolution occurs solely by natural selection that brings forth a vertical, bifurcating pattern in the "tree" of life. Divided into two parts, this chapter first reviews current neo-Darwinian "tree of life" versus reticulate "web of life" polemics as they have been debated in high-profile academic journals, and secondly, the historical context of discovery of the various means whereby genes are transferred laterally is sketched. Along the way, the reader is introduced to how HGT contradicts some of the basic tenets of the neo-Darwinian paradigm.
\end{abstract}

\footnotetext{
N. Gontier $(\bowtie)$

AppEEL_Applied Evolutionary Epistemology Lab, University of Lisbon,

Lisbon, Portugal

e-mail: nlgontier@fc.ul.pt
} 
Keywords Tree of life - Web of life - Horizontal Gene Transfer • Transformation • Transduction - Conjugation - Gene transfer agents • Modern Synthesis • Extended Synthesis - Biomedical sciences

\begin{abstract}
Imagine that in a coffee house you brush up against a guy with green hair. In so doing, you acquire that part of his genetic endowment, along with perhaps a few more novel items. Not only can you now transmit the gene for green hair to your children, but you yourself leave the coffee shop with green hair. Bacteria indulge in this sort of casual, quick gene acquisition all the time. (Margulis and Sagan 2000: 93)
\end{abstract}

\title{
1 Introduction
}

The concept of "horizontal gene transfer" (HGT) and also the recognition that HGT occurs abundantly across all three domains of life have only been brought to the attention of the wider evolutionary community from the early 1990s onward (Gogarten et al. 1989; Hilario and Gogarten 1993; Doolittle 1999; Rivera and Lake 2004; Syvanen and Kado 1998). This wider recognition correlates with advances made in molecular phylogenetics (Woese et al. 1990), in particular with prokaryotic systematics, but the results also extend to eukaryotic life forms. Molecular phylogenetic reconstructions have brought forth numerous inconsistencies, incongruences, and anomalies in the traditional "tree of life." Whole-genome sequencing techniques of various species belonging to all three domains of life evidence that species genomes contain significant amounts of "foreign DNA," i.e. genes that are neither shared with their ancestral lineages, nor the result of random mutations of existing genes. In short, they are not acquired from parental species and thus not the result of genealogical or reproductive descent with modification. Rather, these foreign genes are acquired outside the genealogical descent line, by means of HGT (Goldenfeld and Woese 2007; Zhaxybayeva and Doolittle 2011: R243-4).

HGT refers to various processes by which biological individuals can acquire genes coming from outside the germ line and the means by which genes are exchanged either between distinct organisms with different genealogical histories, or between distinct genomes present in the same organism. Genes can be transferred between prokaryotes, between prokaryotes and eukaryotes (in both directions), between eukaryotes, and between viruses and pro- and eukaryotes.

In prokaryotes, HGT occurs via bacterial transformation, phage-mediated transduction, plasmid transfer via bacterial conjugation, via Gene Transfer Agents (GTAs), or via the movement of transposable elements such as insertion sequences. The genes that underlie significant prokaryotic metabolic pathways such as energy metabolism, cofactor/vitamin metabolism, and antibiotic resistance were mostly acquired by HGT (Iwasaki and Takagi 2009). Because these genes play such a crucial role in prokaryotic evolution, several authors claim that it is the main way in which evolutionary novelty arises in these microorganisms (Lopez and Bapteste 2009; Doolittle 2005; Fournier et al. 2011; Ragan et al. 2009; Zhaxybayeva and Doolittle 2011). 
In eukaryotes, HGT is mediated by processes such as endosymbiosis, phagocytosis and eating, infectious disease, and hybridization or divergence with gene flow, which facilitates the movement of mobile genetic elements such as transposons and retrotransposons between different organisms (Keeling and Palmer 2008; Arnold 2008; Ryan 2004, 2009).

Although HGT has been dubbed "biology's next revolution" (Goldenfield and Woese 1997), most of the processes by which HGT takes place were already discovered in the early twentieth century. There are merely fine lines to be drawn between HGT and endosymbiosis or processes of infectious heredity, and data on HGT were originally interpreted from within a general symbiosis theory. Bacterial conjugation and phage-induced transduction of bacterial DNA were dubbed instances of "hereditary symbiosis" and "infective heredity" by their discoverer Lederberg (1952). Also today, a significant amount of scholars continue to consider HGT, endosymbiosis, and infectious heredity as aspects of a larger, symbiogenetic (Gontier 2006, 2007; Margulis 1970; Moran and Jarvik 2010; Ryan 2006, 2009; Sapp 1994, 2003, 2004), or a more general reticulate evolutionary theory (Andam et al. 2010; Doolittle and Bapteste 2007; Zhaxybayeva and Doolittle 2011; Keeling and Palmer 2008).

Many of the observations made on HGT furthermore track back to, and associate with major milestones and advances made within standard evolutionary theory. Research on bacterial transformation tracks back to the identification of genes as the bearers of genetic material. The study of bacterial conjugation and transduction is associated with increasing insight into cell cytology, cytoplasmic inheritance, and evo-devo which are milestones in evolutionary thinking that first developed during the "eclipse of Darwin." Research on mobile genetic elements associates with epigenetics.

The discrepancy in time between the first observations of HGT in the early twentieth century and the wider acceptance and recognition of its abundant occurrence in the 1990s, as well as the remarkable associations of advances in knowledge on reticulate evolution with the standard milestones of evolutionary thought, raise a series of interesting anthropological and epistemic problems. Why have these data been ignored for so long by mainstream evolutionary scholars? Why have they not been incorporated into the Modern Synthesis? And why are these data argued to contradict the Modern Synthesis?

Divided into two parts, this chapter first investigates the historical factors that contributed to the wider recognition of HGT, and secondly, the various mechanisms by which HGT occurs are sketched against their general context of discovery.

\section{Reticulate Evolution and Webs of Life}

Tree diagrams are nowadays the most common means by which the evolutionary descent of species is illustrated. The concept of evolution is currently so intertwined with these tree diagrams that both laypeople and scientists alike often find it difficult to think about evolution without envisioning phylogenetic tree images. Tree of life 
imagery serves as an educational aid where, by analogy with natural trees, evolutionary tree diagrams depict life as having originated from one single trunk that bifurcates into branches that in turn split into twigs whereupon the leaves grow. The leaves represent the species, the twigs are analogous to the genera, the branches to the phyla, and the trunk symbolizes the last and single universal common ancestor of life.

Tree metaphors and treelike structures were first drawn in pre-evolutionary times to depict the genealogical descent of natural phenomena. These non-evolutionary genealogical tree diagrams were later adopted by Charles Darwin and Ernst Haeckel to understand and depict evolutionary descent relationships of biological species. If evolution is a fact of life, then how does one depict the "evolutionary descent with modification" of the various species that ever existed? How do we illustrate life's early origins and extinctions? Do speciations from unicellular organisms to multicellular life forms entail some kind of "progress," and "linear arrangement," or do "the bottom of branches ... appear like circles" (Darwin 1837/1838: 1-27)? Darwin pondered about these questions in his Notebook B that he filled in 1837-38. Inspired by familial pedigree thinking and genealogical tree models that illustrate the natural history of languages (Gontier 2011), on the one hand, Darwin favored a "tree of life metaphor" because species do not "really pass into each other." On the other hand, he wondered whether "The tree of life should perhaps be called the coral of life, base of branches dead; so that passages cannot be seen," but he added that such an imagery "offers contradiction to constant succession of germs in progress" and "makes it excessively complicated" (Darwin 1837/1838: 25-6).

Eventually, both in his notebook and also in the Origin, the tree diagram made it. The famous "I think" diagram depicts a first hypothetical branching diagram that Darwin used to hypothesize about species relatedness and speciation, and in his Origin of Species, Darwin (1859) made ample use of the "tree of life" metaphor in his Chap. 4, the chapter wherein he advanced his views on natural selection. The Origin also contains a famous diagram on how species hypothetically speciate over time by means of natural selection. Nonetheless, the first evolutionary "tree of life" that depicts actual, chronological evolutionary-descent relationships between species was first drawn by Haeckel (1866).

Darwin thought of other ways to depict evolutionary descent relations, and it is no coincidence that the tree metaphor and branching diagrams were favored. Evolution by means of natural selection is conjectured to occur either when diverging species gradually split off from existing branches (cladogenesis), or when existing species gradually and linearly evolve into new species (anagenesis). Cladogenesis naturally brings forth a bifurcating and ramificating pattern (Doolitte and Bapteste 2007), while anagenesis, though conceived to be gradual, nonetheless entails a break between the parental and the newly evolved species.

Scholars coming from different evolutionary research fields have increasingly come to question the utility and accuracy of tree diagrams in depicting the evolution of various strands of life. Advocates of punctuated equilibria theory (Eldredge and Gould 1972) have long reported that tree diagrams do not adequately portray the often rapid speciation events of eukaryotes. Because the tree of life tends to have a maximum species diversity at the end of the tree (Gould 1986), it does not 
adequately depict the many (mass-)extinction events that have occurred throughout life's evolution (for discussions, see the fourth issue of the 2010 edition of Evolution, Education and Outreach, and Serrelli and Gontier 2015).

Critique has also come from symbiologists and microbiologists. As early as 1905, Constantin Mehrezkowsky provided a prolegomena for a symbiogenetic double-origin theory of life, a view he fully developed and illustrated with a phylogenetic reconstruction in the 1910 translation of his 1909 work (depicted in Carrapiço's chapter, this volume). He assumed that life evolved from two separate "Plasmaarten" (life forms), Mycoides Plasma (Mykoplasma) and Amöboides Plasma (Amoeboplasma). Both life forms were conjectured to have evolved separately, and afterwards, they engaged in a "primary symbiosis." Mereschkowsky (1910: 280, my translation):

Until now, there was the general conviction, that the tree of life was a single one. The task set forth in this work, is to demonstrate that there are two trees of life, and that each tree originated on its own and independently from the other one, and this probably happened in different periods of earth's history. These trees partly developed on their own and independently from one another and partly stringed together and closely grew and developed together. Both trees are responsible for the diversity of the organic beings. The idea of a unity of organic nature has to be abandoned in favor of the idea of nature's duality.

A couple of years later, in 1915, Hermann Reinheimer was the first to introduce the concept of a "web of life" (Carrapiço, this volume), to describe the multiple cases of symbiosis and symbiogenesis that occur in the animal and plant kingdoms. And also Margulis has pioneered in developing "tree of life" and 5-kingdom iconographies that include the symbiogenetic mergings that underlie the evolution of the eukaryotic kingdoms (Whittaker and Margulis 1978; Margulis 1998, 1991; Margulis and Schwart 1997).

Both Lederberg (1952: 425) and Sapp (1994, 2009) have argued that most tree diagrams and evolutionary theories in general present a "sterile" view of evolution. And today, critique on the tree of life is based on incoming data on massive HGT in prokaryotes as evidenced by molecular phylogenetic reconstruction techniques. Current phylogenetic depictions of the evolution of life increasingly attempt to include the many reticulate means by which the micro-organismal world evolves. Such phylogenetic reconstructions look more like a "web" (Doolittle 1999), "network" (Gogarten 2000; Kunin et al. 2005), "net" (Williams et al. 2011), "ring" (Rivera and Lake 2004), or "cobweb" of life (Ge et al. 2005), which connects the splitting branches of the tree at the level of the roots, the trunk, the numerous branches, twigs, and nods. The emerging network-like diagrams draw interconnecting evolutionary lines within and across life's three domains, i.e., the Archaea, Bacteria, and Eukarya (Woese et al. 1990), and the connecting lines also crisscross with viruses, i.e., genetic agents traditionally conceived as non-living structures.

In this part, we first sketch the historical context wherein biochemical, molecular elements became used as markers to infer genealogical descent. Secondly, we investigate when the concepts of "reticulate evolution" in general and "HGT" in particular became associated with molecular phylogenetic reconstructions of the "tree" and "web" of life, and we end with briefly sketching the polemics that underlie tree versus web of life iconographies. 


\subsection{Molecular Phylogenetics and the Origin of Life}

In the early 1960s, Pauling and Zuckerkandl proposed that "chemical paleogenetics" could aid paleontology and systematics in reconstructing the natural genealogies of species by comparing the uniform, constant rate of "semantide changes" ("DNA, RNA, and polypeptides") in related species (Zuckerkandl and Pauling 1962). In 1965, they wrote their seminal papers "Evolutionary divergence and convergence in proteins" and "Molecules as Documents of Evolutionary History" (Zuckerkandl and Pauling 1965a, b), wherein they called this uniform, constant rate of semantide change "the molecular evolutionary clock." Their work was foundational for neutral evolution theory (genetic drift), as it was developed by Motoo Kimura, and it launched the field of molecular systematics where the rate of molecular change in protein and gene sequences is used to deduce genealogical relationships and speciation events, an approach they characterize as "...the most rational, universal, and informative molecular phylogeny" because “... in macromolecules of these types there is more history in the making and more history preserved than at any other single level of biological organization" (Zuckerkandl and Pauling 1965b: 360).

Molecular phylogenies lend insight into evolutionary history in the following three ways, they give: "(1) the approximate time of existence of a molecular ancestor common to the chains that are being compared; (2) the probable aminoacid sequence of this ancestral chain; and (3) the lines of descent along which given changes in amino-acid sequence occurred" (Zuckerkandl and Pauling 1965b: 360). The method itself, however, cannot provide exact dates in time. To give an exact estimate of divergence in geological time, scholars need to calibrate and compare their results with the fossil record (for a history and discussion, see Morgan 1998; Morange 2000; San Mauro and Agorreta 2010).

Ever since, scholars have reconstructed ancestral-descent relationships by comparing the sequences of proteins (Fitch and Margoliash 1967) and DNA and RNA sequences (Sanger and Coulson 1975). Technological advances in molecular genetics, such as the polymerase chain reaction or PCR technique (Mullis 1983), and more recent shotgun sequencing (Messing et al. 1981; Staden 1979), high-throughput sequencing, and barcoding (Hebert et al. 2003), enable comparisons ranging from single-nucleotide sequences to whole genomes. Comparative studies allow the various species to become "rooted" into common ancestors that trace back to the very origins of life on earth (de Magalhães et al. 2010; Pettersson et al. 2009; Schuster 2008).

Molecular phylogenies are currently providing the primary tools to classify prokaryotic life. Prokaryotic organisms rarely fossilize, and before the advent of molecular genetics, scholars were limited to reconstructing morphological phylogenies. Due to increasing possibilities to sequence large data sets, including whole genomes and "metagenomes," molecular phylogenetics has from the 1970s onward provided bacteriologists with a means to identify the genetic diversity and relatedness of living prokaryotic beings, as well as to infer, from these comparisons, their evolutionary emergence in time. At present, these techniques even enable microbiologists to identify and distinguish bacterial species currently known 
only by their genetic sequence because scholars have so far been unable to isolate them for morphological, electron microscopic study (Eisen 2007; Chen and Pachter 2005; Handelsman et al. 1998; Hugenholz et al. 1998).

In recent years, worldwide, large-scale projects have been set up such as ToLwebthe Tree of Life Web Project (http://tolweb.org); the NSF-funded AToL-Assembling the Tree of Life (http://www.phylo.org/atol) and GoLife-Genealogy of Life (http://www.nsf.gov/funding/pgm_summ.jsp?pims_id=5129\&org=DEB) projects; iTOL — the Interactive Tree of Life Project (http://itol.embl.de); and the Tree Thinking Group (http://www.tree-thinking.org). These all share the ambitious goal to once and for all determine every species' evolutionary ancestry and place on the tree of life.

One of these projects already originated in the late 1970s. With the goal to build the universal tree of life, Woese and Fox (1977; Fox et al. 1980) began comparing specific sections of genetic material that is present in both unicellular and multicellular life. They selected subunits of ribosomal RNA (rRNA) as biochemical markers and focused on 16S rRNA for prokaryotes and 18S rRNA for eukaryotes. Ribosomal RNA is a type of RNA that enables protein synthesis. Incoming results led Fox and Woese to undo the classic distinction of life into pro- and eukaryotes, and instead, they proposed that prokaryotes (or Monera) should be divided into two separate kingdoms: Archaebacteria and Eubacteria. Eukaryotes represented a third "urkingdom" that has a "chimeric nature," because it contains genes coming from both lines. The consequence was that there exist three "urkingdoms" or monophyletic lines of descent instead of two: the Archaebacteria, Eubacteria, and Eukaryota.

This tripartite division of extant life is incompatible with the conventionally accepted view in which living systems are divided into two basic phylogenetic categories, prokaryotes and eukaryotes. However, the eukaryotic cell is now recognized to be a genetic chimera, whose evolutionary origins we do not yet understand. (Fox et al. 1980, 458)

In 1990, Woese and colleagues would take things one step further and demonstrate that there is sufficient reason to completely separate "Eubacteria" from "Archaebacteria" and to classify them as distinct domains of life (Bacteria and Archaea) that, together with the eukaryotes (Eukaryota), delineate the "threedomain hypothesis" or three-domain classification of life (Woese et al. 1990). The new comparisons also evidenced that Bacteria stand quite on their own and that Archaea are more closely related to eukaryotes, the third domain. The threedomain classification also came with an rRNA-based tree of life (Woese et al. 1990: 4578) where LUCA, the last universal common ancestor wherefrom these domains evolved, i.e., the "universal" and single root of the tree, still remained to be identified (Lawton 2009).

In later publications, Woese (1998) and other scholars (Doolittle 1999, 2005; Martin 1999; Villarreal 2006) increasingly came to question whether one such universal common ancestor will ever be found, and instead, Woese raised the possibility that the roots of the tree are multiple. Also, Margulis (1991) has conjectured that although all eukaryotes probably share a last eukaryotic common ancestor (LECA), a single origin for prokaryotic life forms is less likely. 
The original rRNA trees did not take HGT into account. In fact, to enable Woese to draw his early trees, he had to ignore any such events. However, later work (Woese 1998) made it clear that HGT is quite common in prokaryotes which made him join the previous claims made by scholars such as Gogarten et al. (1989, Hilario and Gogarten 1993) that HGT occurs abundantly (Goldenfeld and Woese 2007). Ever since, scholars have been developing means to identify the numerous instances of HGT by applying molecular phylogenetic reconstruction techniques.

Nonetheless, mainstream phylogenetic reconstructions continue to ignore HGT events. In 2006, in association with the iTOL project, a team lead by Bork (Ciccarelli et al. 2006) introduced a new "tree." To fit all life forms, they had to turn the tree into a circle, which was quite innovative, but the scholars also consciously ignored HGT data. HGT has long been considered a seldom event in evolutionary history. In this view, it does not threaten the common tree iconography of evolution because one can look for "core genes" shared by all major taxa. Bork's iconography, for example, was based upon 31 orthologous "core genes" present in all 191 examined lineages coming from both pro- and eukaryotic species.

HGT scholars criticized Bork's tree for representing a "tree of one percent" (Dagan and Martin 2006). Doolittle (2009: 221) contended that

Enthusiastic TOLers see this TOC, no matter how little of the actual phenotypedetermining information or history the organisms they wish to classify it encompasses, or how extreme the algorithm used to derive it, as a triumph of the Darwinian method and a vindication of their belief in the TOL. It is, in their view, the genealogy upon which Darwin thought classification could safely, and ultimately must, rest. This is I think a misreading of history and a non-trivial re-formulation of the goals of phylogenetic practice.

Because these phylogenetic reconstructions attempt to find the universal "roots" of the tree of life, this research also extends toward fields such as exobiology and astrobiology, i.e., fields that study the origin of life on this and possible other planets. Researching the origin of life does not form a basic tenet of the Modern Synthesis. The standard neo-Darwinian paradigm provides a theory of biogenesis: It explains how existing life brings forth new life forms by means of natural selection. Thomas Henry Huxley, for example, called research on abiogenesis, which in his epoch associated with theories on spontaneous generation and epigenetics, to a halt. Research on abiogenesis, or how life evolves out of inorganic physical, and biochemical particles, developed mostly after the foundation of the Modern Synthesis. Theories on the RNA world, "spontaneously generated" or self-organizing autocatalytic biomolecular networks, proteinoid microspheres, etc., evolved in association with increasing knowledge of the biochemical elements that build the living cell, and in association with molecular phylogenetic reconstructions. An RNA world, for example, was already envisioned by Woese (1967); the article by Fox et al. (1980) demonstrated that the first life forms were chemoautotrophs instead of heterotrophs, and it were molecular sequences of RNA and DNA viruses that demonstrated that these genetic agents most likely evolved before life (Villareal and Defilipps 2000; Villarreal and Witzany 2010). 


\subsection{First Usage of the Terms HGT and Reticulate Evolution}

Evidence for HGT dates back to discoveries of bacterial transformation, conjugation, and transduction, but concepts such as "HGT" and "reticulate evolution" date to later periods in time. HGT between the eukaryotic nuclear genome and cellular organelles such as mitochondria and chloroplasts was first hypothesized to occur by early symbiologists including Margulis (1970), and genetic exchange was later confirmed by Wolf and Delguidice (1987) and Gray et al. (1989). More evidence for naturally occurring gene transfer between organisms was reported by Trevors et al. (1987), Coughter and Stewart (1989), Daniels et al. (1990), Doolittle et al. (1990), and Gupta and colleagues (Gupta and Signh 1994; Golding and Guptha 1995).

One of the first usages of the concepts "HGT" and "reticulate evolution" comes from Ambler et al. (1979), Hartley (1980), Busslinger et al. (1982), and Champion et al. (1980). Champion, in a review paper on the evolution of gram-negative Pseudomonas fluorescens bacteria, wrote that:

Bacteria can acquire new phenotypic characters either from other bacteria by Horizontal gene transfer or through manipulation of their own genetic material (vertical evolution). ... In addition, it has long been recognized that a group of bacterial strains are usually delineated from other groups, not by the exclusive possession of a single or several traits, but by possessing a particular set of traits. These facts have been taken to indicate a reticulate mode of evolution in which the potential uniqueness of any group of strains has been undermined from extensive horizontal exchange of genetic material from closely to distantly related groups. The pseudomonads may be a good example of this phenomenon. (Champion et al. 1980: 506, my italics)

In 1984, Syvänen (1984a and also see Syvänen 1984b, 1986 and 1987) speculated that conserved regions in mammalian beta-globin possibly resulted from "crossspecies gene exchange," and a year later, he wrote a seminal and very interesting article on "Cross-species gene transfer; implications for a new theory of evolution," wherein he hypothesized that:

\footnotetext{
... genes are transferred and expressed among all species, and that such exchange is facilitated by, and can help account for, the existence of the biological unities, from the uniform genetic code to the cross-species similarity of the stages of embryological development. If this idea is correct, the uniformity of the genetic code would allow organisms to decipher and use genes transposed from chromosomes of foreign species, and the shared sequence of embryological development within each phylum would allow the organism to integrate these genes, particularly when the genes affect complex morphological traits. The cross-species gene transfer model could help explain many observations which have puzzled evolutionists, such as rapid bursts in evolution and the widespread occurrence of parallelism in the fossil record. (Syvänen 1985: 333)
}

Peter Gogarten and colleagues (Gogarten et al. 1989; Hilario and Gogarten 1993) focused on ATPase genes as genetic markers for molecular phylogenetic reconstructions and suggested that these genes were acquired by "Horizontal Gene Transfer," which made the authors start to debunk the single tree of life before Woese did. ATPase genes encode for proteins and enzymes that play a crucial role in cell membranes by enabling the uptake of foreign material (Gogarten et al. 1989; Hilario and Gogarten 1993). The ATPase genes differ between all three "urkingdoms of life" (Fox 
et al. 1980), and are therefore a good genetic marker to root the tree. The comparison of ATPase genes also groups Archaea closer to Eukaryota and both are more distant from Bacteria, which converges with, and also confirms, Woese's et al. (1990) classification of life into three separate domains based upon comparisons of rRNA subunits. ATPase genes also give discrepancies in what regards gene versus species trees and Hilario and Gogarten (1993: 118) therefore concluded that:

The finding that genes were exchanged between distantly related species implies that a single gene phylogeny can no longer be readily interpreted as a species tree. To determine the evolution of species more than one gene tree should be considered. (Hilario and Gogarten 1993: 118)

Ever since, scholars who study HGT have been introducing new metaphors and visualizations that capture the reticulate evolutionary pattern brought forth by HGT. Already in 1999, Ford W. Doolittle provided a now classic reticulate image of the "web" that sought ways to visualize the massive HGT, and later, in 2005, he expanded his image in order to include the symbiogenetic acquisition of chloroplasts and mitochondria in eukaryotic life forms (Doolittle 1999, 2005; Doolittle and Bapteste 2007; Bapteste et al. 2005, 2009). Rivera and Lake (2004) have introduced a "ring of life" that depicts the chimeric origin of the eukaryotic genome; Dagan and Martin (2009) have provided networks that depict both the horizontal and vertical exchanges between distinct microbial lineages; in 2010, Luis Villarreal (Villarreal and Witzany 2010) provided a first attempt to root the tree of life with viruses, and he tried to illustrate the susceptibility of all three domains of life to "viral colonization" (and also see Mindell and Villarreal 2003).

\subsection{Was Darwin Wrong?}

The new reticulate icons of evolution are often treated with gigantic suspicion. In 2009, the January 21st issue of the New Scientist magazine featured a cover titled "Darwin was wrong: Cutting down the tree of life." The front page of the magazine featured a tree of life drawn by the Russian artist Yulia Brodskaya. In that tree, some branches crossed and the trunk was divided into several different lineages. In the journal, Lawton (2009) wrote an article on HGT titled "Axing Darwin's tree; The tree of life is an iconic image, but it could be time to fell it" and the editorial was titled "Uprooting Darwin's tree." The tree, the editorial, and the article received enormous media and scholarly attention, and most of the reactions were negative. Dennett et al. (2009: 25) wrote a very angry letter which opened as follows:

What on earth were you thinking when you produced a garish cover proclaiming that 'Darwin was wrong' ...? First, it's false, and second, it's inflammatory. And, as you surely know, many readers will interpret the cover not as being about Darwin, the historical figure, but about evolution. ... You have made a lot of extra, unpleasant work for the scientists whose work you should be explaining to the general public. We all now have to try to correct all the misapprehensions your cover has engendered. 
Indeed, emotions ran high. Dennett and his cowriters pointed the finger in dispraise, arguing that the cover, the editorial, and the article gave green light to creationists and that it undermined scientific evolutionary thought.

These criticisms were out of proportion. For one, trees are the number one icon for many world religions, and they were also used in pre-evolutionary societies to depict non-evolutionary, abstract and logical, or genealogical descent relations of divine and earthly phenomena. Debunking tree images therefore hardly feeds into creationist thought (Gontier 2011). Secondly, reticulate evolution can be proven by an enormous amount of data, and these theories in no way lend credibility to the ideas of creationism. Not trying to incorporate these findings into educational imagery, now that would be against science. Moreover, the tree that featured on the cover of New Scientist is still quite conventionally looking. There are many more extravagant "tree of life" images circulating around in science these days that do not even slightly resemble an actual, natural tree. It is therefore highly interesting to see such emotional responses made "ex auctoritate" when a public image such as the tree of life is being criticized. Nonetheless, evolution is no longer synonymous with natural selection, and the reticulate evolutionary mechanisms deserve their educational tools.

As early as 2004, the American Journal of Botany dedicated a special issue to the tree of life of plants (see especially the paper by Palmer et al. 2004). The overall message conveyed by the issue was that the early symbiogenetic origin of plants, as well as their numerous hybridization events, disable one to straightforwardly draw the tree of plants as a branching pattern wherein lineages solely split into new ones.

In response to the outbursts of some of the "hardcore" neo-Darwinians, scholars working on HGT and symbiogenesis have been stirring up debate in the August 2009 issue of the Philosophical Transactions of the Royal Society, B: Biological Sciences, which featured a theme issue titled "The network of life: genome beginnings and evolution" (Ragan et al. 2009). Epistemological aspects of the tree of life debate were discussed in the September 2010 issue of Biology and Philosophy (O’Malley et al. 2010). In 2011, Gribaldo et al. edited a special issue for the journal Research in Microbiology on "Archaea and the tree of life," and O'Malley and Koonin (2011) edited an issue titled "Beyond the Tree of Life" for Biology Direct.

As can be deduced from the issue's titles, the authors pled for a replacement of the tree of life image by a "network" or "web" of life. During horizontal evolution, evolutionary lineages can cross, melt, and dissolve into one another. By analogy, the roots of the tree, and even its distinct branches, can cross or melt together, and an increasing amount of scholars acknowledge that life probably evolved from multiple roots that evolved into various trunks.

Critique also came from virology. Trees of life include extant and extinct biological species, but should it end there? Virologists are increasingly suggesting that viruses should be included in phylogenetic reconstructions as circling around the tree of life, where the existing roots, trunks, branches, and twigs are constantly "colonized" by viral agents. The code words by which viruses can enter the tree of life iconography are again lateral gene transfer, symbiogenesis, and infective heredity. 
... The 'Tree of Life' concept has been severely undermined and cannot apply to ... large scale HGT processes ... or explain the role of viruses .... . Yet a tree-like structure of genetic evolution is observed in all domains of life, including most viruses. Thus HGT is colonizing an existing tree from non-ancestral (viral) sources. However, 'Tree-thinking' which explains tree growth by ancestral variation and natural selection continues to be vigorously defended leading many to dismiss the prokaryotes as 'odd-balls' that evolve differently from other life. Evidence now compels us to revise our definition and vision of the Tree of Life to include viruses. ... Reticulate evolution and symbiosis apply to all life and must now be incorporated into our conceptual framework .... (Villarreal and Witzany 2010: 699)

If we include viruses, should we also include the overall abiotic environment? Darwin (1837/38: 23-24), for example, already wondered how the environment, divided into air, land, and water, could be brought into tree of life imagery, and how a similar environment would cause for affinity in the major branches of life's tree.

Would there not be a triple branching in the tree of life owing to three elements air, land and water, and the endeavour of each one typical class to extend his domain into the other domains, and subdivision three more, double arrangement. - if each main stem of the tree is adapted for these three elements, there will be certainly points of affinity in each branch.

In 2014, in a special issue on "The tree of life in ecosystems: evolution of plant effects on carbon and nutrient cycling" published in the Journal of Ecology, an additional requirement was added to the tree of life; namely, such an iconography should be able to feature the various biochemical cycles as well as the hierarchical relations life endorses with the biotic and abiotic environment (Cornelissen and Cornwell 2014). Also in 2014, Kathleen Scott called out for contributions to a special issue for the journal Life, titled "Modern Phylogeny: The Three Domains of Life" wherein she was aiming for chapters that include metabolic cycles and physiological capabilities such as photosynthesis and mutagenesis, which also need phylogenetic reconstructions and overall integration into our evolutionary descent imagery (the call can be read at http://www.mdpi.com/journal/life/special_issues/ phylogeny, and the issue is currently forthcoming).

The incoming data can no longer be banned from evolutionary iconographies. Nonetheless, one can wonder whether patterns of evolution can or cannot be inferred from the tree of life imagery (for a discussion, see the 2008 special issue for the Journal of Systematics and Evolution edited by Hong et al. 2008). It seems a logical and scientific necessity to demand that a universal "tree of life," or more general educational aids that visualize the evolution of life, should be able to at minimum fit in all forms of life, all time periods, and it should adequately depict all types or modes of descent. This in turn raises interesting questions on whether evolutionary descent iconographies should be able to provide insight into the major mechanisms by which life evolves, the hierarchies of life and its major transitions, as well as what shapes such depictions should take on.

Debating such questions merges fluently with the ongoing debates on the adequacy of the Modern Synthesis and the necessity to extend its scope. Including data acquired from molecular phylogenies, exobiology, virology, and ecology implies an inclusion of fields that were marginalized during the formation of the Synthesis. 


\subsection{Conclusion to Part 1}

Because there are so many special issues and numerous papers that debate these epistemic questions, I have chosen to guide the reader to the literature rather than to give an in-depth analysis myself. Over the past years, scholars have been trying to put more and more ranks on the tree of life, and they have been trying to visualize and incorporate the numerous evolutionary mechanisms whereby life evolves in order to make evolutionary iconographies truly universal. On the other hand, scholars have questioned the possible to draw one universal tree of life that is able to illustrate all of life's complexity, thereby arguing that each rank should have its own tree or network of life.

At present, it is unclear whether all of life's complexity can indeed be depicted into one tree, web, or one iconic image. Illustrating the common, and not so common, descent of life can only be done right if we take into account the different evolutionary theories and mechanisms that explain life's descent. Moreover, the drawing of the tree highly depends on the conceptual classification framework one uses: Different species concepts, different definitions of life, different evolutionary theories, and different evolutionary mechanisms provide different evolutionary diagrams.

Throughout history, the tree has strongly contributed to our understanding of the evolutionary process. Science is associated with images, and these images therefore help in the dissemination and acceptance of ideas. It therefore becomes all the more important that our scientific illustrations convey the right messages, and the origin of life out of non-life, dissipative structures, autocatalytic adaptive systems, RNA worlds, symbiogenesis, HGT, viral colonization, and hybridization are most certainly among those messages.

\section{Mechanisms of HGT}

Medical microbiology had a life of its own, but it was almost totally divorced from general biological studies. Pasteur and Koch were scarcely mentioned by the founders of cell biology and genetics. Instead, bacteriology was taught as a specialty in medicine, outside the schools of basic zoology and botany. Conversely, bacteriologists scarcely heard of the conceptual revolutions in genetic and evolutionary theory. (Lederberg 2003: 287)

While concepts such as "Horizontal Gene Transfer" and "reticulate evolution" date back to the 1980s and 1990s, bacterial transformation, conjugation, and transduction were already observed in the early decades of the twentieth century. Many of these observations track back to, and associate with major milestones and advances made within standard neo-Darwinian evolutionary theory. However, these discoveries are rarely featured in historical reviews on the onset of evolutionary thought. Instead, such reviews will guide their reader through a set of historical milestones that include the following: the introduction of cell theory by Mathias Schleiden and Theodor Schwann in the late 1830s; the introduction of natural selection theory by Charles Darwin in 1859; the temporary "eclipse of Darwinism" in the late 
nineteenth century due to advances made in ecology, symbiology, and epigenetics (that includes what we today call "evolutionary developmental biology"); the rediscovery and synthesis of Mendelian hereditary laws with Theodor Boveri and Walter Sutton's chromosome theory of inheritance, Darwin's natural selection theory, and various aspects of mutation theory; the rise of theoretical population genetics; the foundation of the Modern Synthesis in the 1940s; the discovery of the structure of hereditary material in the early 1950s; the subsequent development of molecular genetics; and the current plea to extend the Modern Synthesis in order to integrate both presynthetically (but marginalized) and postsynthetically evolved theories.

In this part, we detail how insights into the mechanisms that underlie HGT correlate with these major advances in evolutionary thought. The discovery of bacterial transformation correlates with the discovery of DNA as the bearer of hereditary material. Insights into bacterial conjugation and phage-induced transduction of bacterial DNA associate with increasing knowledge into cell cytology, cytoplasmic inheritance, and evo-devo. And transduction and knowledge on mobile genetic elements bring us to the epigenetic era. Though ignored by the standard evolutionary framework, even more puzzling is that discoveries that currently enable us to understand HGT have from the very onset been recognized as major breakthroughs in the biomedical sciences. In fact, one way by which one can detail the history of HGT is by guiding the reader through the various Nobel Prizes that have been awarded in the category of Physiology or Medicine from the early twentieth century onward. Why was there this discrepancy between the biomedical and evolutionary sciences?

For one, evolutionary biology is a diachronically oriented research field: It studies the natural history of species, and therefore, it is directed toward the past. In contrast, the biomedical sciences' epistemic stance is futuristic: By trying to understand the current causes of disease, they try to find cures that will remedy disease in the future. That is why they do not form part of the evolutionary sciences, neither academically speaking in what regards the division of the sciences, nor epistemologically speaking in what regards their theoretical outlook. It is only recently, partly due to the wider recognition of HGT, that the biomedical and evolutionary sciences are becoming synthesized.

Secondly, the Weismann (1885) barrier put an end to neo-Lamarckian evolutionary theories that developed during the "eclipse of Darwin." Ontogenetically acquired traits were no longer contended to feed back into the germ line. The founders of the Modern Synthesis therefore drew clear barriers between ontogeny and phylogeny. HGT, on the contrary, associates with "infective heredity," i.e., the study of diseases and foreign DNA that are acquired during the individual's life span.

Thirdly, because the phylogenetically oriented neo-Darwinian field was out of epistemic reach for biomedical scholars, instead, they associated their discoveries with more ontogenetically oriented disciplines, namely symbiology, ecology, developmental biology, and epigenetics (what we today designate as "evolutionary developmental biology"). These research schools all developed in the late nineteenth century, and they did so in close association with one another, because these fields study the various lifetime-interactions species engage in, either with 
one another or with the abiotic environment. For that very same reason, these latter disciplines have evolved outside or in the margins of the standard evolutionary framework.

As a philosopher of science, my aim here is not to review insights on the biochemical, molecular structures that underlie HGT processes, but to explain the basics in simple terms, as well as to briefly situate the discoveries in time, thereby highlighting the major implications they have for general evolutionary theory.

\title{
3.1 History of Infectious Disease: The Origin of HGT Research in Symbiology, Ecology, Developmental Biology, and the Biomedical Sciences
}

\begin{abstract}
Genetics, symbiotology, and virology have a common meeting place within the cell. There is much to be gained by any communication between them which leads to the diffusion of their methodologies and the obliteration of semantic barriers. (Lederberg 1952: 32)
\end{abstract}

As already mentioned in the introduction to this volume, there is only a fine line to be drawn between studies on symbiosis, infectious heredity, and HGT. This becomes especially striking when one reconstructs the historical origins of lateral transfer studies.

Symbiology, medicine, bacteriology, virology, and overall microbiology are fields that developed their frameworks in the late nineteenth-century period that has been designated by Huxley (1942) as the "eclipse of Darwinism." The eclipse of Darwinism is a period in history that demarcates a demise in the adherence to natural selection theory in favor of more ecological, symbiotic, and ontogenetic (including cell cytological) frameworks. Symbiotic research paralleled ecological research and both developed outside Darwinian and neo-Darwinian theory (Sapp 1994). Ecology, for example, only became integrated in the 1960s, and even today, symbiology remains unintegrated.

From the mid-nineteenth century onward, symbiologists such as de Bary (1861) and Van Beneden $(1873,1875)$ had pointed toward parasitic symbiotic microorganisms as the cause of plant and animal diseases. The "golden age" of bacteriological and microbiological fields as well as the advent of the biomedical sciences with the "germ theory of disease" are thus ultimately driven by insights into symbiosis.

The biomedical sciences are an outgrowth of (1) increased knowledge of bacteria, protozoan microorganisms, and eventually also viruses as causal agents of disease (Beijerinck 1898; Cohn 1875; d'Herelle 1917; Iwanowski 1892; Koch 1876, 1882; Pasteur 1880; Laveran 1880; Lewis 1879; Mayer 1886; Twort 1915) and (2) knowledge on immunology and its associated researches on vaccination therapies, serology, and chemotherapies (Ehrlich 1877, 1879a, b; Jenner 1798). From its onset, the biomedical sciences have emphasized the possibility of horizontal exchange of biochemical substances between various organisms and horizontal transmission of these substances outside of the germ line, during various stages of organismal development. 
As early as 1717, Mary Wortley Montagu introduced an immunization technique against smallpox (Variola) in England. During extensive stays in Turkey, she learned that rubbing the scabs from individuals infected with smallpox against carved skin of healthy individuals leads to the development of only a mild form of smallpox. Somehow, there must therefore have been a form of horizontal transmission from the infected pustules to the healthy individuals, which rendered the latter less vulnerable to the disease. Her work led to the introduction of inoculation and injection techniques to develop immunity against various diseases and these techniques eventually found all research on vaccinations. Soon after, scholars would conduct similar experiments with less virulent cowpox which proved to also cause immunity against Variola (Case and Chung 1997), and eventually, Jenner (1798) would introduce a first cowpox-based "vaccine" against smallpox.

Such inoculation and vaccination experiments, which, in hindsight, are per definition based upon the artificially induced horizontal transfer of biochemical substances, or the artificially induced endosymbiosis of foreign cells into a host, became the primary means by which scholars identify and study disease.

In 1884, Robert Koch, one of the founders of the germ theory of disease, published his etiology of tuberculosis that proves that the Tubercle bacillus is the disease-causing agent of tuberculosis. Koch (1884) was able to cultivate pure strains on blood serum and he proved that inoculation in guinea pigs caused disease. From this work, he derived 4 postulates that serve as testing devices to identify microorganisms as disease-causing agents: (1) The microorganism must be present in sick organisms and absent in healthy ones; (2) doctors have to be able to isolate the disease-causing organisms from infected organisms and grow pure strains of them; (3) inoculation of isolated cultures must cause disease in healthy organisms; and (4) after inoculation, the microorganisms must be found in the infected host, and they must be identical to the originally identified pathogens.

In 1886, D.E. Salmon and Theobald Smith, the first Americans to study bacteria as disease-causing agents, developed a new means to induce immunity against contagious diseases by injecting whole, heat-killed cells of virulent strains in healthy individuals. And four years later, two students of Koch, Behring and Kitasato (1890), developed immunizing techniques against Diphtheria and Tetanus.

Immunology became a subfield of the medical sciences due to advanced knowledge on human blood and the plasma it contains. Immunology encompasses the field that studies the reactions of the body against infectious agents and unwanted substances. The injection of foreign agents such as bacteria or viruses into the skin or the veins of organisms causes the body to react with an immune response. This immune response involves the production of antibodies (mostly consisting of white blood cells) that attack the antigens of the pathogen. Antigens are chemical substances found on the surface of infectious agents. When the pathogens are rendered harmless, the body has created a "memory" of the infectious agent: It maintains the specifically generated antibodies which ensure protection against future encounters with the pathogen.

Scholars first learned about such complex interactions between antibodies and antigens through the works of Paul Ehrlich and Ilya Ilyich Mechnikov 
(Élie Metchnikoff). Ehrlich (1877, 1879a, b) first identified the various types of human blood cells that exist, thereby founding the field of serology. In 1891, he discovered antibodies that cause immunity against plant toxins, work that led him to develop one of the first theoretical frameworks to understand immunology (Ehrlich 1898, 1900; Ehrlich and Morgenroth 1902). His "side-chain theory" understands the workings of serum on toxins (antibodies on antigens) as a chemical reaction whereby the molecules of the serum and the toxin bind to one another. Most importantly, he thought that immunology was inheritable and horizontally transmittable, in mammals especially via lactation from mother to offspring (Ehrlich 1892a, b).

In 1882, Mechnikov experimentally introduced thorns from a tangerine tree into the larvae of starfish and observed that specific cell types surrounded the thorns, which made him assume they protect the larvae by eating the foreign material. In 1884 , he was able to confirm his idea, by observing that "eating cells" destroyed fungal spores that he introduced in Daphnia (a freshwater flea). Later in his career, he discovered that mammalian white blood cells engulf and kill the Anthrax bacterium. Carl Friedrich Claus proposed Mechnikoff to call the cells phagocytes (eating cells), and Mechnikov introduced the term "phagocytosis" to describe the process of elimination by eating and conjectured that it lies at the basis of cellular immunity (see Karnovsky 1981; Tauber 2003; Tan and Dee 2009 for a discussion). Today, we know that phagocytes are a group of motile white blood cells, and mast and dendritic cells that play crucial roles as primary defenders of immunity. They eat harmful pathogens and eliminate debris. Phagocytosis is furthermore the mechanism suggested today to underlie primary, secondary, and tertiary endosymbiosis, whereby the acquisition of the symbionts is understood as a failed digestion of the independently evolved cells (for a discussion, see Zook, this volume).

New microscopes enabled a better visualization of the microorganisms, and symbiology theory (especially parasitism), more so than natural selection theory, facilitated a better theoretical conceptualization of the acquisition and development of infectious diseases, while immunizing techniques such as inoculation experiments and vaccination therapies enabled protection against disease. Similar inoculation experiments underlie the discovery of bacterial transformation by Frederick Griffith in 1928.

Investigating immunological processes entails a recognition that symbiotic and coevolutionary relations have evolved between hosts and pathogens, their antibodies, and antigens. And this recognition necessitates research in ontogeny because such interactions take place during the life span of the individual.

At the turn of the twentieth century, von Faber (1912) took the issue one step further by theorizing that ontogenetically acquired, parasitic, and beneficial symbiotic relationships can become hereditary. Von Faber's notion of "erbliche Zusammen leben" became translated by Cowles (1915) as "hereditary symbiosis" which became understood as a major driving force of symbiogenesis by scholars such as Buchner (1921), Wallin (1927), and Lederberg (1952). In fact, Lederberg, who discovered bacterial conjugation and phage-mediated transduction, understood both as instances of "hereditary symbiosis" and "infective heredity." 


\subsection{Bacterial Transformation}

Transformation was first observed by Griffith (1928) in the context of medical research on the nature and cause of pneumonia. Griffith conducted various experiments whereby he inoculated healthy organisms with virulent strains of the bacteria that cause pneumonia and in the process, he discovered that some bacteria transformed. The study of the underlying patterns and mechanisms whereby bacteria transform also played a crucial role in the discovery of genes as carriers of hereditary information (Avery et al. 1944). Before we turn to history, we first outline the basics of bacterial transformation.

Bacterial transformation is a type of HGT whereby living bacteria take up naked genes from their surroundings, including genes coming from decomposing bacteria (Chen and Dubnau 2004; Dubnau 1999; Downie 1972; Redfield et al. 1997; Sisco and Smith 1979). The acquired genes can range from small DNA fragments such as transposons to plasmids, and even the donor's entire bacterial chromosome can become absorbed by the recipient (Akamatsu and Taguchi 2001). Uptake of plasmids or an entire chromosome occurs mostly under artificial laboratory conditions, during genetic engineering experiments, while the lateral acquisition of small DNA fragments occurs abundantly in natural settings (Mandel and Higa 1970; Johnsborg et al. 2007).

The acquired DNA fragments can be used for DNA repair (Hoelzer and Michod 1991); it can function as a nutritional source (Finkel and Kolter 2001); the acquired genes can become part of the bacterial genome, or it can integrate into possible plasmids already residing inside the bacterium (Fig. 1). The acquisition and insertion of DNA fragments into the bacterial genome enable genome growth, and the integrated DNA often not merely changes the bacterium's genetic makeup, it also changes functional metabolism.

How and why bacteria take up foreign DNA particles is still not completely understood (Chen and Dubnau 2004; Dubnau 1999). Bacterial types such as Streptococcus pneumonia appear to have a natural competence to take up foreign DNA, an ability that is biochemically "programmed" in their genes. This competence relates to the morphology of their bacterial envelope and membrane, as well as their pili (filaments attached to the cell's surface) (Sisco and Smith 1979; Redfield et al. 1997). Pili are also involved in bacterial conjugation, discussed in the next part.

Transformation is a costly biochemical process, and bacteria mostly engage in DNA uptake when they find themselves in a state of starvation, under harsh environmental conditions, or when they contain damaged DNA (Engelmoer and Rozen 2011). In addition, transformation is one of the means by which bacteria such as $E$. coli naturally acquire resistance genes to antibiotics (Anderson 1968; Cohen and Miller 1969, 1970; Cohen et al 1972). Stanley Cohen, Annie Chang, and Leslie Hsu demonstrated that "the introduced R-factor DNA can persist in such cells as an independently replicating plasmid, and can express both the fertility and antibiotic resistance functions of the parent R factor" (Cohen and Miller 1970: 2110). "R factors" stand for "resistance transfer factor" or "antibiotic resistance factors."

Bacteria can also integrate DNA from bacterial viruses. Mandel and Higa (1970), for example, demonstrated that in the laboratory, E. coli bacteria can take 


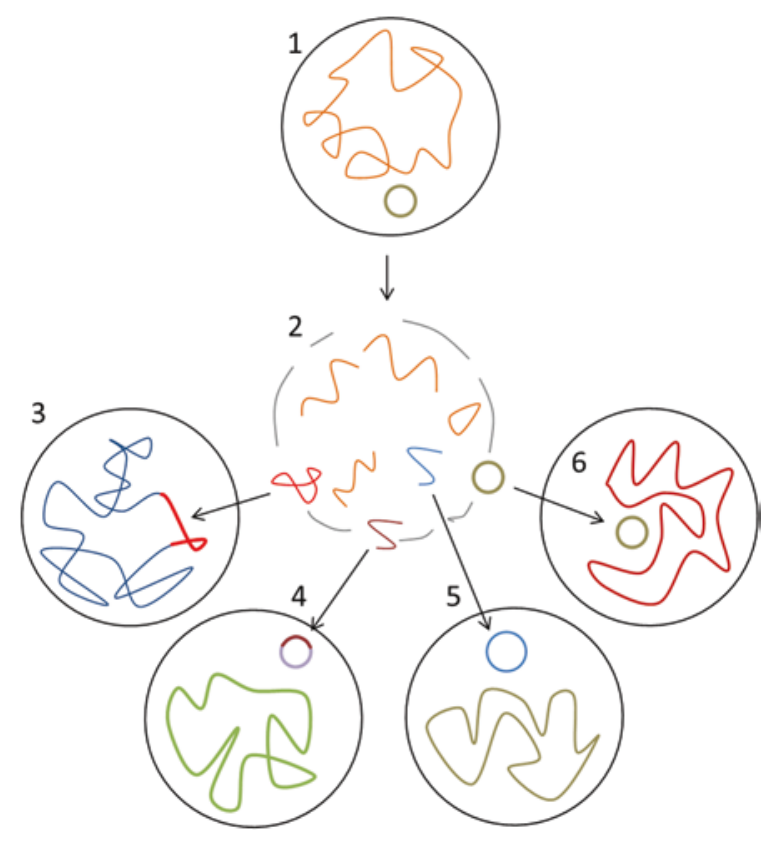

Fig. 1 Examples of bacterial transformation. 1 A bacterium with its bacterial genome and a plasmid. 2 The bacterium dies, the cell membrane and the bacterial chromosome disintegrate, and some fragments and the plasmid are released from the dead bacterium. 3 A DNA fragment is absorbed by a recipient cell and becomes integrated into the bacterial chromosome. $4 \mathrm{~A}$ transposon carrying antibiotic resistance gene(s) is absorbed by a recipient cell, and the transposon becomes integrated into the bacterial plasmid. 5 A DNA fragment is incorporated into a recipient bacterial cell, but the DNA is not integrated into the bacterial genome; instead, either the DNA fragment is broken down and used as a nutritional source or the DNA fragment remains in the cell as extrachromosomal DNA. 6 The plasmid from the donor cell becomes integrated into the recipient bacterium

up genes coming from the lambda bacteriophage. And already in 1951, Victor Freeman reported on HGT from a bacteriophage to an avirulent Corynebacterium diphtheria and indicated that such transfer renders the bacteria virulent:

Regardless of the fact that the underlying mechanism is not understood, the knowledge that avirulent cultures of $C$. diphtheriae can become virulent in the presence of specific bacteriophage is of importance to any consideration of the many perplexing problems that have confronted bacteriologists and epidemiologists interested in the study of diphtheria. If the virulence of the diphtheria bacillus should prove dependent not only on its toxigenic ability and its invasive power but also on the degree of its association with a specific bacteriophage, then some of the difficulties involved in understanding the complex problems of bacterial metabolism and immunity as they occur in the diphtheria case or carrier might be partially solved. (Freeman 1951: 686)

Bacterial transformation raises interesting questions on adaptive environmental responses as well as biochemical "communication." Experiments demonstrate an increase in competence to transform when the bacteria are somehow threatened, and the mere possibility to take up foreign genes depends upon the biochemical recognition of exogenous DNA in its surroundings and biochemical capacities to transport and insert 
the foreign DNA particles. Insofar as bacteria seem to prefer to take up naked DNA similar to their own genetic makeup, it must involve some kind of biochemical recognition of this similarity. Furthermore, upon death, many bacteria release their genes to the surroundings, and one can wonder whether such an act requires a higher-order, group explanation: Does such release resemble some kind of "altruistic group behavior"?

\subsubsection{Griffith's Inoculation Experiments}

Around the turn of the twentieth century, Pneumococci (Streptococcus pneumoniae) became indicated in causing lobar pneumonia in humans. Neufeld (1902) and Neufeld and Händel (1910), working at the Koch Institute, had classified various strains into 3 different types. In 1917, Avery and colleagues added a fourth type (Downie 1972: 2).

With the goal to abstract immune sera (antibodies) against pneumococci, the British microbiologist and physician Frederick Griffith (1877-1941) abstracted the various bacterial types from the mucus coming from the lower airways (sputum) of infected humans that had developed lobar pneumonia. He subsequently "grew" these bacterial strains in the belly of mice to then abstract them again after which he tested whether these bacteria correspond to the types he found in the human sputum. Afterward, he combined the sputum with the type serum and injected them into healthy mice to see how they react to various strains of the bacterial types.

What was striking was that the mice that developed inflammation would often die from a bacterial strain different from the one it was injected with. Contrary to his contemporaries, who assumed the fixity of bacterial types, Griffith's research led him to conclude that the bacterial types underwent modification: They were able to "transform" and acquire new virulent functions. Such transformation, Griffith (1928: 139) furthermore noticed, was "the property of the whole strain in each case."

But what exactly happened? Several explanations were possible: Either the various bacterial types and strains merely represent several stages of the same individual, much like a caterpillar is a stage in the life cycle of a butterfly; or the cultures were not pure; or infection with one type might make infection with another type more likely; or perhaps during reproduction one type would randomly mutate to another type; or perhaps environmental conditions played a role because transformation of type was more likely to occur under the skin than in the bloodstream.

To find answers, Griffith (1928: 133-6) conducted further experiments and observed that when avirulent pneumococci were grown on a blood agar plate for 24 hours, they would develop colonies that appear morphologically "Rough" to the observer. Instead, virulent colonies would have a "Smooth" glistering appearance. Nonetheless, there were circumstances in which he inoculated mice with an attenuated Rough strain ( $\mathrm{R}$ strain), and yet, they would die from sepsis. When these individual's blood was inspected, they would contain Smooth strains ( $\mathrm{S}$ strain) with "well-marked capsules" (a substance that surrounds the bacterial envelope). The well-marked capsules, we now know, are coats made up of sugar and proteins that protect the virulent strains against recognition by the host's antibodies. Rough 
strains are rough because they do not have this protective shield, and the infected body therefore recognizes the intruder and renders it harmless.

So at some point, a conversion occurred and Griffith (1928: 141-158) subsequently investigated "whether an avirulent $\mathrm{R}$ pneumococcus can be transformed into the virulent $\mathrm{S}$ form by growth in the body of mice." Several of these experiments went as follows (Fig. 2). First, he cultured pure R and pure S strains. When he inoculated healthy mice with living attenuated non-encapsulated $\mathrm{R}$ strains, the mouse stayed healthy, thereby confirming that the $\mathrm{R}$ strain is avirulent. When he inoculated mice with the living encapsulated and virulent $S$ strains, the mice would die, thereby confirming that the $\mathrm{S}$ strain is virulent. When he inoculated mice with dead $\mathrm{S}$ strains that he killed through heating, the mice would also remain healthy. But, when he combined living $\mathrm{R}$ strains with the heat-killed $\mathrm{S}$ strain and injected them into mice, the mice would die. Inspection of the blood of these dead mice would evidence the presence of living S strains.

He therefore concluded that transfer of substances from the dead $\mathrm{S}$ strain to the living R strain happened, enabling the R strain to transform into the virulent S strain. Griffith (1928: 166): “... the attenuated organisms actually make use of

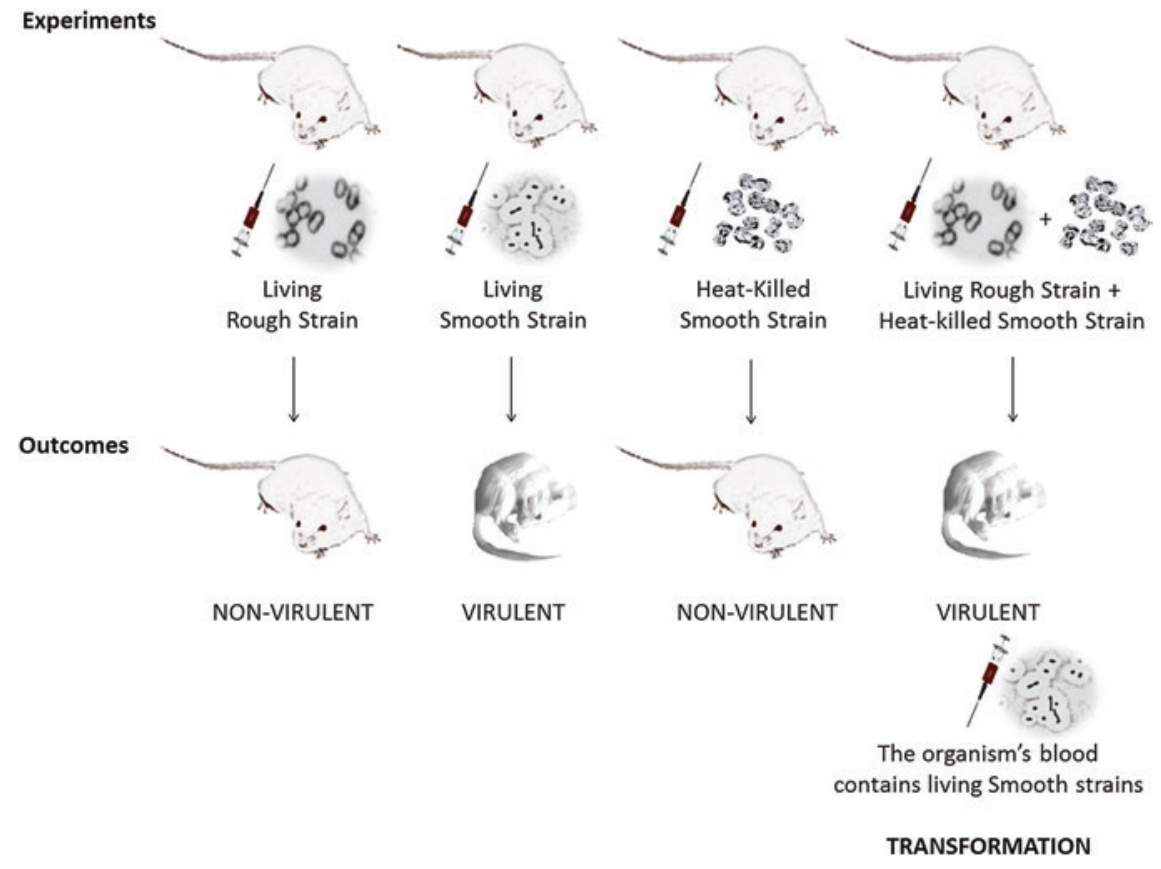

Fig. 2 Schematic of Griffith's transformation experiments. Living Rough pneumococcal strains and heat-killed Smooth strains are harmless for the mice, which proves that strains with this morphology are non-virulent. Living Smooth pneumococcal strains are virulent and cause death. A combination of living Rough avirulent strains with heat-killed Smooth strains made the mice die. When he examined the blood of the dead mice, he found living Smooth and thus virulent strains. The Rough strains had transformed from being avirulent to being virulent, and Griffith speculated that the Rough strains had acquired a "transforming factor" from the dead virulent strain 
the products of the dead culture for the synthesis of their S antigen. An R strain is most readily transformed into the $S$ variety when the killed culture used is of the same serological type as that from which the R strain was derived."

He also noted that such transformation occurred when inoculation happened in the skin or the belly. In the bloodstream, the $\mathrm{R}$ strains are immediately rendered harmless by immune responses of the body, thereby disabling any transformation to a virulent $\mathrm{S}$ strain. But, Griffith noted that such rough morphology is adaptive for the bacteria, because they can lie latent in the body and switch to a virulent stage when the body is infected with new, virulent strains (Griffith 1928: 172).

This is the principle of lateral transfer by transformation. Living bacteria can snatch compounds of dead bacteria. Griffith, however, did not know what the nature was of the transforming factor and thought that the capsule, which is made up of proteins, had something to do with the transformation from $\mathrm{R}$ to $\mathrm{S}$ strains.

\subsubsection{The Avery-MacLeod-McCarty Experiments}

Griffith's experiments were confirmed by several scholars including Neufeld, Levinthal, and Bauerhenn, as well as by scholars from the Rockefeller Institute for Medical Research (Avery et al. 1944: 137). Oswald Avery was a medical doctor who had been studying the capsules that surround the virulent strains, because he thought that these capsules were responsible for disease. From 1928 to 1931, work done by Martin H. Dawson and Richard Sia, members of Avery's laboratory, enabled the "conversion" of $\mathrm{R}$ into $\mathrm{S}$ forms in a test tube, in vitro. More specifically, they accomplished the growth of " $R$ cells in a fluid medium containing antiR serum and heat-killed encapsulated S cells" (Avery et al. 1944: 137).

While Griffith had induced transformation in various types and strains of pneumococci, in all of Avery, MacLeod, and McCarthy experiments, they focused on the transformation of an attenuated R type II strain (itself derived from a virulent S culture of pneumococcus type II) to virulent type III S strains (Avery et al. 1944: 139). Their experiments were successful.

The reproduction of the experiments subsequently enabled the Rockefeller scholars to begin isolation studies on the "transforming factor" in 1935, work that was first performed by James Lionel Alloway and later by M. MacLeod, McCarthy, and Avery himself. In a series of experiments, the scholars used various techniques that specifically and selectively break down DNA, RNA, proteins, and lipids, and in 1944, in a now famous article, they revealed that the transforming factor that enables non-capsular, avirulent $\mathrm{R}$ strains to transform into capsular $\mathrm{S}$ forms, must be made up of DNA. They concluded as follows:

Equally striking is the fact that the substance evoking the reaction and the capsular substance produced in response to it are chemically distinct, each belonging to a wholly different class of chemical compounds. The inducing substance ... appears to be a highly polymerized and vicious form of sodium desoxyribonucleate [deoxyribonucleate]. On the other hand, the Type II capsular substance, the synthesis of which is evoked by this transforming agent, consists chiefly of a non-nitrogenous polysaccharide constituted of glucose-glucuronic acid units 
linked in glycosidic union. The presence of the newly formed capsule ... confers in the transformed cells all the distinguishing characteristics of Pneumococcus Type III. Thus, it is evident that the inducing substance and the substance produced in turn are chemically distinct and biologically specific in their action and that both are requisite in determining the type specificity of the cell of which they form part. (Avery et al. 1944: 152)

Particularly, the last point is important. The scholars underlined that DNA is the enabler of capsule formation (made up of proteins), but DNA itself is made up of a substance different from the substance that makes up the capsule. For the authors, this suggested that DNA carries hereditary information, information that is specific and differential. It does not provide the material to make the capsule; rather, it carries the information on how to make it. Their work countered the then prevailing notion, brought forth by scholars such as Phoebus Levene, that DNA was a simple and repetitive structure made up of the same elements. They further noted how odd they found it to reach these conclusions based upon the study of "immunological techniques."

Their work, and also Griffith's, presents a prototypical example of how empirical evidence often precedes theory. As Downie (1972: 2) notes, one of the reasons Griffith conducted so many experiments to confirm his results was probably because he was "conditioned to believe that bacteria existed in immutable types." And also Avery was at first reluctant to accept the incoming results from his collaborators, who continued their research during a leave of absence due to thyroid intoxication by their senior.

Avery, MacLeod, and McCarthy's work was nonetheless well received and even popularized by Scientific American (Morange 2000: 33). But although the work and the results were recognized, it remained difficult for scholars to think through the consequences. Because both Griffith and Avery's team artificially induced transformation under laboratory settings, it was assumed that such transformation did not occur in natural settings. The authors themselves noticed that: "Transformation of types has never been observed to occur spontaneously and has been induced experimentally only by the special techniques outlined earlier in this paper" (Avery et al. 1944: 140). The idea that hereditary information can be transmitted horizontally under natural conditions during ontogeny (terms they never used to describe these phenomena) was too far away from the idea that hereditary information is transmitted vertically during sexual reproduction.

That it is indeed DNA that carries hereditary information was later confirmed by Hershey and Chase (1952) at the Cold Spring Harbor Laboratory, in their famous experiments with $\mathrm{T} 2$ bacteriophages and E. coli bacteria. They used different radioactive isotopes to color the proteins that make up the bacteriophage's capsid and the DNA that makes up the core of the phage's head, in order to track which parts enter the bacterial cell upon infection and which parts enable the production of new phages. They concluded that it is the phage's DNA that becomes injected upon infection, while the protein coat remains attached to the surface of the bacterium. And the phage's progeny mainly inherits genetic material rather than proteins.

We have shown that when a particle of bacteriophage T2 attaches to a bacterial cell, most of the phage DNA enters the cell, and a residue containing at least 80 per cent of the 
sulfur-containing protein of the phage remains at the cell surface. This residue consists of the material forming the protective membrane of the resting phage particle, and it plays no further role in infection after the attachment of phage to bacterium. These facts leave in question the possible function of the 20 per cent of sulfur-containing protein that may or may not enter the cell. We find that little or none of it is incorporated into the progeny of the infecting particle, and that at least part of it consists of additional material resembling the residue that can be shown to remain extracellular. Phosphorus and adenine ... derived from the DNA of the infecting particle, on the other hand, are transferred to the phage progeny to a considerable and equal extent. We infer that sulfur-containing protein has no function in phage multiplication, and that DNA has some function. (Hershey and Chase 1952: 54)

\subsection{Bacterial Conjugation}

A plasmid is an extrachromosomal, circular-shaped, double-stranded DNA molecule. In other words, plasmids do not form part of the bacterial chromosome, but reside in the cytoplasm of the bacterial cell. Here, they can replicate autonomously from the latter. Plasmids are central agents for HGT by means of bacterial conjugation (Thomas 2000; Griffith et al. 2000), whereby one copy of the doublestranded DNA molecule that makes up the plasmid is laterally transferred from a donor bacterium to a recipient. Bacterial conjugation requires cell-to-cell contact between two bacterial organisms, and these organisms have a different morphology: One has a plasmid and a sex pilus (a sexual appendage), and the other has not. Pili are hairlike filaments made up of pilin proteins that extend from the bacterial cell surface (Proft and Baker 2009). There exist different types of pili: Some enable motility in which case they are called common pili or fimbriae (Mattick 2002), while others enable conjugation. When the pili enable bacterial conjugation, they are called conjugative pili or sex pili. The genes required to produce pili are encoded in the conjugative plasmid.

During bacterial conjugation in E. coli, one such sex pilus of the donor bacterium attaches itself to the recipient bacterium and pulls the latter cell closer (Fig. 3). The membranes join, and the lateral exchange occurs. During the exchange, one strand of the double-stranded DNA molecule that forms the plasmid of the donor cell is passed on to the recipient. Thus, the plasmid itself does not, in its entirety, move from the donor to the recipient cell. What happens is that the double-stranded DNA of the plasmid is cleaved, and a single-stranded plasmid is transferred to the recipient. After the transfer, both the donor and the recipient synthesize the complementary strand of the plasmid DNA, thereby rebuilding the plasmid into a double-stranded DNA molecule. After conjugation, and thus after acquisition of the plasmid, the recipient cell is also able to engage in bacterial conjugation.

Bacterial conjugation was first discovered in the E. coli K-12 strain by Lederberg and Tatum (1946). The E. coli K-12 strain is a laboratory strain that was abstracted from a human patient's stool (Bachmann 1972), and ever since, it has been cultivated in various laboratories around the world. When Lederberg and Tatum first reported on bacterial conjugation, they did not know how the mechanism of transfer worked. Their experiments on "direct hereditary interaction of one 
Donor

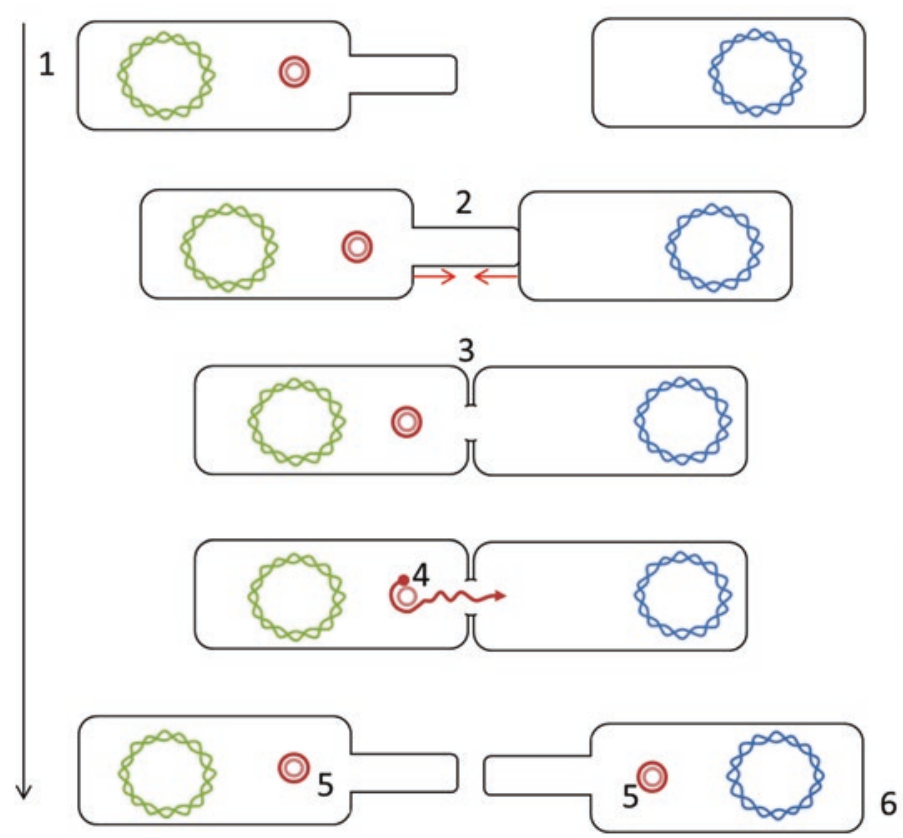

Recipient

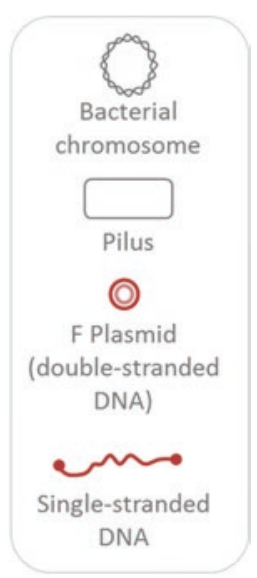

Fig. 3 Steps in bacterial conjugation of E. coli. 1 On the left, a donor bacterium (F + cell) carrying an $\mathrm{F}$ plasmid. Right, a recipient cell $(\mathrm{F}-)$ that does not have an $\mathrm{F}$ plasmid. 2 The conjugative pilus of the donor bacterium attaches to the recipient bacterium and pulls the latter closer. 3 The cells become connected. 4 A single DNA strand of the plasmid is transferred. 5 Both the donor and the recipient synthesize the complementary DNA strand which enables the restoration of the double-stranded plasmid molecule. 6 Because of the transfer, the recipient cell now also becomes an $\mathrm{F}+$ cell that can donate plasmids to other $\mathrm{F}-$ cells

bacterial type with another" involved mixing two mutated strains of E. coli $\mathrm{K}-12$, each deficient in the synthesis of certain proteins and enzymes disabling them to grow. One strain could produce what the other lacked, so the strains were complementarily insufficient for their lack of synthesis of these elements. However, when the two strains were mixed together, new colonies emerged. So the bacteria appeared to have exchanged what the other lacks to reestablish growth, and the authors presumed that this occurred via bacterial "recombination" (bacterial mating) or "hybridization," though a "complete analogy cannot be drawn at present between the inheritance of bacterial characters and the Mendelian processes of higher forms" (Lederberg and Tatum 1946: 681).

But what had been exchanged and how? Did one or both strains engage in a form of "nutritional symbiosis" (Lederberg and Tatum 1946: 766), or did they exchange genes in order to repair their DNA (Griffiths 2000)?

Major insights into the mechanisms were brought forth by the Lederberg couple as well as by Luigi-Luca Cavalli Sforza, William Hayes, François Jacob, and 
Ellie Wollman, first independently and later in close collaboration (Holloway and Broda 1996). Seven years later, in a letter to Nature, Hayes (1952) reported that bacterial conjugation was unidirectional, going from a donor to a recipient. Lederberg et al. (1952) and, a year later, Hayes (1953) discovered the "F Fertility factor" that enables the initiation of bacterial conjugation in E. coli. It was Esther Lederberg who first coined the term "Fertility Factor."

In E. coli, the F factor can also integrate into the bacterial chromosome through homologous recombination, a process first described by Cavalli Sforza (1950). As a factor that can both exist independently in the cytoplasm and integrate into the bacterial chromosome, the F plasmid was considered an example of an "episome," a term first coined by Jacob and Wollman (1958; Wollman and Jacob 1955). Integration of the $\mathrm{F}$ factor into the bacterial chromosome results in a "High-frequency recombination cell" or Hfr cell (Williams, this volume).

Plasmids were considered by Lederberg (1952: 403) to "comprise part of the genetic determination of the organic whole," and he understood such elements to evolve in a non-Mendelian fashion, by "infective heredity" (Lederberg 1952: 413) which made them examples of "hereditary symbiosis" (Lederberg 1952: 415 1955).

Finally, bacterial conjugation has mostly been studied in gram-negative bacteria such as the E. coli, but it also occurs in gram-positive bacteria (Grohmann et al. 2003). Gram-positive bacteria are furthermore able to transfer the entire double-stranded plasmid DNA (Grohmann et al. 2003; Scott and Zähner 2006). Heinemann and Sprague (1989) have additionally demonstrated that genetic transfer from conjugative E. coli to eukaryotic yeast organisms (Saccharomyces cerevisiae) can happen which proves that transfer can occur from pro- to eukaryotes.

\subsubsection{Bacterial Conjugation and the Acquisition of Antibiotic Resistance}

Bacterial conjugation was the first suggested mechanism by which bacteria acquire resistance to antibiotics. Antibiotics are substances produced by certain bacteria that have detrimental effects on other bacteria. When antibiotic substances penetrate the bacterial cell, it can target cellular components such as ribosomes, proteins, or the bacterial cell wall and induce decomposition leading to bacterial cell death. Antibiotic resistance occurs when bacteria evolve genes that disrupt the function of antibiotic substances, by disabling penetration of the bacterial cell wall, or by altering its target. Bacteria have also evolved means to simply push the antibiotic substances out of the cell, and they have evolved enzymes that decompose the antibiotic substances (Andersson and Hughes 2010; Allen et al. 2010).

By the 1950s, several antibiotics, including Chloramphenicol, Tetracycline, Streptomycin, and Sulfonamide, had become widely fabricated and administered to sick patients (Lederberg 2003: 288). And in a little less than 10 years, the first reports came in that bacteria had acquired resistance to these antibiotics.

These reports came from Japan where Ochiai et al. (1959), Akiba et al. (1960), and Mitsuhashi et al. (1961) had discovered naturally occurring antibiotic 
resistance in Shigella bacteria. These are gram-negative bacteria that include $S$. dysenteriae bacteria responsible for dysentery and they are also closely related to Salmonella and E. coli. The scholars observed that several dysentery patients became non-responsive to the four different types of antibiotics.

In the feces of the dysentery patients, they also found E. coli bacteria that were equally resistant to these antibiotics. The case studies brought to light that the acquired drug resistance of Shigella often occurred against all four types of antibiotics, even when patients were only administered one type of antibiotics. Neither the antibiotics themselves nor the interaction between the antibiotics and the Shigella bacteria could therefore underlie the acquired resistance. Instead, it was suggested that Shigella bacteria acquired antibiotic resistance from resistant E. coli strains that exist together in the intestinal canal of dysentery patients. The scholars tested the hypothesis and were able to artificially induce (in vitro): "(1) multiple-resistant clones of Shigella by mixing the cultures of the drug-sensitive Shigella and the multiple-resistant E. coli, and (2) mutual transfer of resistance between Shigella and Escherichia" (Akiba et al. 1960: 225).

At the time, all three canonical forms of HGT among bacteria had been reported, and based upon the principle of exclusion, the Japanese scholars theorized that the means by which antibiotic resistance was acquired was by bacterial conjugation.

From the results obtained [...] transformation is not believed to be responsible for this phenomenon. The authors have not succeeded in the isolation of phage from resistant strains which is infective to give resistance to sensitive recipients. From this result, transduction is hardly considered as an essential mechanism. Therefore, recombination or conjugation may be the most probable mechanism involved. (Akiba et al. 1960: 226)

The Japanese scholars' knowledge on antibiotic resistance was transferred to a general Western audience by Watanabe (1971), who furthermore associated the acquisition of antibiotic resistance genes with Lederberg's notion of "infectious heredity" which in turn was inspired by symbiology jargon. The drug resistance genes, dubbed "Resistance factors" or "R factors," were thought of as "episomes": elements that can either replicate autonomously or integrate into the bacterial chromosome:

We have found ... that the multiple drug resistance factors are carried and transferred by an episome ... . Multiple drug resistance is, therefore, an example of "infective heredity ..." (Watanabe 1971: 87)

As such, they provided another example for the very existence of episomes. Other early reports on transferrable antibiotic drug resistance include the works by Andersön (1968) and Jones and Sneath (1970).

The transmission of antibiotic resistance genes via bacterial conjugation demonstrates how rapid evolution by means of HGT can be. In less than 10 years after the first worldwide administrations of antibiotics, Shigella bacteria were able to acquire and spread this resistance. Some of these resistance genes already existed within the bacteria involved, and other resistance genes have evolved since the massive introduction of antibiotics. The current standard paradigm assumes that 
genetic mutations are "random," and it considers such random mutations to result from "copying errors." Whether or not the evolution of resistance genes is "random" or "directed" remains a topic of considerable research, but the rapidness by which transfer occurs across species outnumbers any suspicion of randomness.

Today, all canonical forms of HGT have been indicated in the acquisition of bacterial resistance. In the case of transduction, this also implies that resistance can be passed on from bacteriophages to bacteria or vice versa, and besides viruses, also fungi and other microorganismal pathogens have acquired resistance for the antibiotics administrated against them.

This again demonstrates intra- and interspecific exchange which in turn indicates an intricate coevolutionary and symbiotic way of living.

\title{
3.4 Phage-Mediated Transduction
}

\begin{abstract}
When Salmonella typhimurium is grown in the presence of a variety of mildly deleterious agents, especially weakly lytic phages, it produces a filterable agent (FA) capable of transferring hereditary traits from one strain to another. Individual filtrates may transduce many different traits, but no more than one in a single bacterium. The activities of a filtrate parallel the characteristics of the donor cells. Nutritional, fermentative, drug resistance, and antigenic characters have been transduced. The new characters are stable after many generations of subcultures. ... (Zinder and Lederberg 1952: 697)
\end{abstract}

Bacteria can become infected by specific viruses called bacteriophages, a word that is often abbreviated as phages. When a bacteriophage attaches to the surface of bacteria, it is able to penetrate the membrane and inject its phage DNA (Fig. 4).

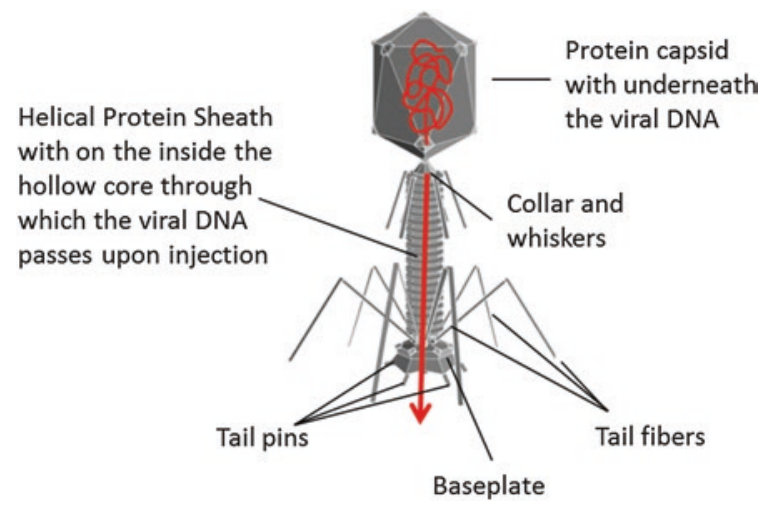

Fig. 4 Morphological structure of a bacteriophage. The phage's DNA is located inside the head of the virus. When the phage infects a bacterium, only the DNA becomes injected into the bacterium. The DNA travels through the helical protein sheath and passes through the bacterial membrane, while the remaining protein-based structure of the phage remains outside the bacterial cell 


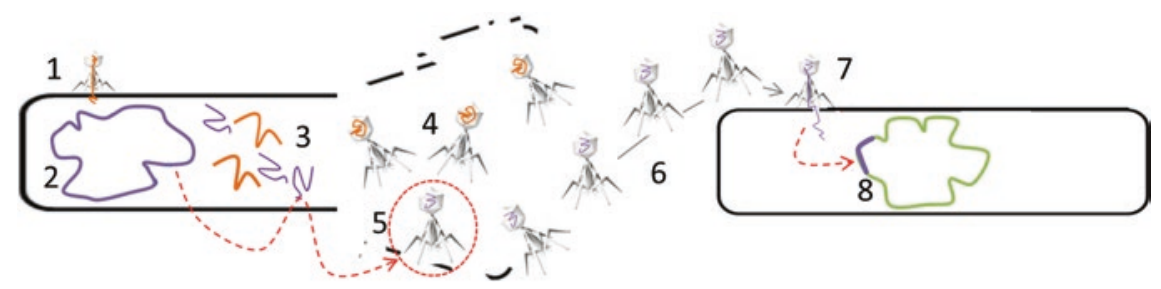

Fig. 5 General transduction or lateral transfer of bacterial genes via bacteriophages. 1 A bacteriophage injects its genes into a bacterium; 2 the bacterial chromosome; 3 phage reproduction causes the bacterial chromosome to disintegrate (lytic phase); 4 the bacterial cell dies, and new virulent phages are released; 5 one phage accidentally packaged bacterial genes instead of phage genes; $6-7$ this defective phage (the transducing phage) travels to another bacterium and injects the acquired bacterial genes; 8 the bacterial genes become integrated into the genome of the recipient bacterium

When the bacteriophage's genes enter a bacterial cell, either they can take on a dormant, non-virulent "prophage" phase (a phase called the lysogenic cycle), or they can make use of the bacterial metabolism to synthesize new phage particles (a phase called the lytic cycle) (Lwoff 1953).

As avirulent, latent prophages, either they integrate into the bacterial genome, or they can reside inside the cell's cytoplasm as integrons or as circular DNA that resembles plasmids. When bacteria carry prophages, they are called lysogenic bacteria. When the phage remains virulent, or during the transition from a latent and lysogenic to a virulent and lytic phase, new virus particles are produced and the bacterial cell undergoes lysis: The cell bursts, and the new viral particles are released into the environment where they can infect surrounding bacterial cells.

Bacterial transduction (Fig. 5) is a form of HGT of bacterial genes that is mediated by bacteriophages (Zinder and Lederberg 1952; Zinder 1992). During the production of new bacteriophages, a bacteriophage accidentally packages bacterial genes instead of bacteriophage genes. When these transducing phages (the with bacterial genes infected phages) are released, they can infect other bacteria, and transfer the aquired bacterial genes. Upon infection with a transducing phage, the bacterial DNA from the donor is incorporated into the bacterial DNA of the recipient via homologous recombination.

In short, during general transduction, bacteriophages accidentally serve as vectors for the transportation and transmission of bacterial DNA. In genetic engineering, phages are one of the preferred means to introduce foreign DNA elements into cells.

Scholars distinguish "generalized transduction," where any gene can become transferred between bacteria via phages, from "specialized transduction" (Griffiths et al. 2000). During specialized transduction, the bacterial genes that are packaged and transferred are specific, and also the location where the transducing genes insert inside the recipient bacterial genome is highly site-specific. An example of specialized transduction involves the transduction of galactose-fermenting genes by the lambda phage in E. coli bacteria (Morse et al. 1956). Lambda phages always insert themselves on a specific site of the bacterial chromosome of E. coli, 
a site that lies right next to the bacterium's galactose-fermenting genes. When the phage transitions to the lytic phase, it packages these specific bacterial genes, which subsequently become the subject of transduction toward other E. coli genes.

\subsubsection{Bacteriophages and Prophages: Parasites or Symbionts?}

Understanding the mechanism of phage-mediated transfer of bacterial genes was greatly facilitated by increased knowledge on bacteriophages (Twort 1915; d'Herelle 1917-1922) as well as the lysogenic and lytic cycles of bacteriophages which first became described by Lwoff and Gutmann in 1950. In this section, we briefly review these advances.

By the end of the nineteenth century, microscopic studies enabled the visualization of bacteria. Bacteria became recognized as agents of disease, and experimental studies enabled their isolation which in turn facilitated their examination. But scholars such as Iwanowski (1891) and Beijerinck (1898) became convinced that besides bacteria, there must exist other pathogenic agents, at the time invisible to the observers. Both scholars came to this knowledge by studying the tobacco mosaic disease, a disease in tobacco plants that, we now know, is caused by the tobacco mosaic virus. Techniques that usually enabled the isolation of bacteria were ineffective in isolating the pathogen that causes the tobacco mosaic disease, and both Iwanowski and Beijerinck therefore speculated about the existence of another contagious substance. Beijerinck called this "contagium vivum fluid" or "living contagious liquid" a virus.

By 1915, Twort discovered that bacteria can be killed or "lysed," and he was able to filter the agents responsible and to experiment with them. In 1917, Felix d'Herelle called the "bacterial parasites" bacteriophages and held them responsible for bacterial cell death.

The existence of bacteriophages in turn induced polemic debates between various scholars about where bacteriophages stem from: Are they naturally part of bacteria? That is, are they part of the genetic endowment of bacteria and are they passed on to future generations? Do bacteria spontaneously "grow" bacteriophages? Or are bacteriophages exogenous structures that infect their bacterial hosts? Another intensely debated subject was whether or not bacteriophages are always "parasitic" and "pathogenic" (d'Herelle 1917), leading to bacterial cell death, or whether bacteriophages could entertain a more mutualistic and commensal "symbiotic" relationship with their host (Burnet 1934), where they switch to a non-virulent form that enables them to entertain a more harmonious relationship.

The debates were settled by Lwoff and Gutmann in 1950, who showed that bacteriophages are the result of an initial infection, but the infectious agents can entertain both virulent and thus parasitic and non-virulent, symbiotic relations with their host. Lwoff and Gutmann (1950) cultured 19 generations of with phage-infected Bacillus megaterium bacteria, and not once were they able to isolate free bacteriophages from their cultures which proved the existence of "vegetative" phages.

These non-active and non-virulent phages were called "prophages," and the scholars also distinguished between the lysogenic and lytic, virulent phase. The 
lytic phase always leads to the death of the bacterial host, while lysogenic bacteria (bacteria that harbor a prophage) transmit the prophage during division. In other words, "Lysogeny is the hereditary power to produce bacteriophage. A lysogenic bacterium is a bacterium possessing and transmitting the power to produce bacteriophage" (Lwoff 1953: 271, my italics, original italic deleted) and a "Prophage is the form in which lysogenic bacteria perpetuate the power to produce phage. Its multiplication is correlated with bacterial reproduction. It seems to be located at a specific site of a bacterial chromosome and to behave in crosses as a bacterial gene" (Lwoff 1953: 272, original italic deleted).

Lwoff and Gutmann came to their discoveries at the Pasteur Institute in France, and at this institute, two of their colleagues, Jacques Monod and François Jacob, were discovering the gene regulatory network that underlies galactose fermentation in E. coli, the first ever to become described.

Phage-mediated transduction was first observed in Salmonella bacteria by Zinder and Lederberg (1952). This is two years after Lwoff and Gutmann (1950) described the lysogenic and lytic phases of bacteriophages, and the same year wherein Hershey and Chase (1952) conducted their experiments. They demonstrated that bacteriophages carry their hereditary material, DNA, inside their head, and that this substance is injected upon infection, while the protein capsid is left behind at the surface. The DNA helix would be described a year later, and genetic material was still assumed to reside both inside and outside the chromosomes of organisms.

Zinder and Lederberg had turned to Salmonella typhimurium bacteria that are closely related to $E$. coli, with the purpose to investigate whether also Salmonella bacteria engage in bacterial conjugation. They did not find evidence for such conjugation, where multiple traits are transferred at once, but found that single traits can become transferred via a bacteriophage known by the name P22 (Lederberg 1956: 271). Around 30 different traits could be transferred via phages between Salmonella bacteria. These traits included resistance to antibiotics (Zinder 1955), flagellar antigens (Sakai and Iseki 1954), and genes involved in fermentation and sugar metabolism (Jacob 1955).

Lederberg and coworkers knew that bacteriophages were involved in the transmission of bacterial genes, as "passive" "vehicles" (Lederberg 1952: 37), but the exact chemical nature of bacteriophages remained obscure. Filtration and sedimentation experiments demonstrated that the substance was below 0.1 micron and it was therefore still beneath microscopic visibility of their time.

Lwoff's distinction between the lysogenic and lytic phases made Lederberg understand the division as being one between "lysogenic symbiosis" and "lethal parasites" (Lederberg 1956: 272). Lysogenic bacteria entertain "stable symbiotic associations" with their prophages (Lederberg 1952: 419), and because prophages can become transmitted to progeny during cell division, he understood it as an example of "hereditary symbiosis" or "infectious heredity."

Lwoff, on the other hand, preferred a more parasitic jargon. In 1965, he shared the Nobel Prize in Physiology or Medicine with François Jacob and Jacques Monod, and in his Nobel lecture, Lwoff used "master/slave" conceptualizations to characterize viruses as "intracellular parasites" that favor "war" over "peaceful coexistence": 
The virus is necessarily an intracellular parasite. The genetic material of a virus has thus entered the cell. The cellular and viral molecules will confront each other, and the fate of the two partners will be decided. Two extreme cases may present themselves. Either the virus will multiply in the cell or else the cell will enslave the virus. Quite naturally, investigation was first directed toward the total war, which offers greater attraction for the combative intellect than peaceful coexistence. (Lwoff 1965, my italics)

Lwoff furthermore noted that "the development of the prophage into bacteriophage is a "mortal disease" because the "prophage is a potentially lethal factor." As already noted in the introduction to this volume, parasitic jargon is nonetheless symbiotic jargon.

It should also be noted that not all bacteriophages can take on a dormant form (Guttman et al. 2002, Chap. 10). Phages such as T2 and T4 are always virulent, and infection always leads to the death of the infected bacteria. Not all phages integrate into the bacterial genome either. Some, such as the P1 phage (Lennox 1955), remain part of the cell cytoplasm, where they take on a circular morphological form that resembles a plasmid or an integron. Alternatively, they integrate into the bacterial chromosome. In both cases (as plasmid or integron, or as an integrated part in the bacterial genome), the prophage can become transmitted vertically over future generations.

Transitions from lysogenic to lytic phases are a relatively rare process: Release of bacteriophages happens in round and about one cell per million in a normal culture (Lederberg 1956: 274) and appears to increase under stress conditions, such as the exposure to ultraviolet light (Jacob 1955). The integration of one prophage also protects the bacterium from becoming infected with other bacteriophages.

\subsubsection{Transduction and Evo-Devo}

Studies on transduction also contributed to the operon concept and the recognition of the existence of gene regulatory networks. The first gene regulatory network was described by François Jacob and Jacques Monod in what regards the genotype-to-phenotype mappings of lactose breakdown or "galactose fermentation" in E. coli (Summers 2006). Today, we know that a distinction can be made between "structural" and "regulatory" genes (Jacob et al. 1960: 30, 31). Structural genes are genes that encode for specific traits, while regulatory genes are genes that can orchestrate the activation and deactivation of structural genes. Regulatory genes encode for proteins that return to the helix where they turn other genes on or off, thereby underlying overall ontogenetic development of bodily form and function.

That a difference exists between regulatory and structural genes was first suggested by Barbara McClintock, in the context of discoveries of transposable or "jumping" genes. And these assumptions were confirmed by Jacques Monod and François Jacob in the 1950s-1960s whom were the first to track how genes encode for metabolism. This first "genotype-to-phenotype" map explains how E. coli metabolizes lactose (milk sugar).

E. coli is a bacterium that naturally occupies the gut of mammals, and all newborn mammals in turn depend upon milk for successful survival. E. coli have 
evolved intricate coevolutionary relations with the mammals they inhabit. E. coli possesses enzymes that enable them to digest and metabolize lactose (the betagalactosidase enzyme), and use of their genetically programmed lactose-metabolizing apparatus, i.e., galactose fermentation, is regulated. Research has shown that in an artificially induced, lactose-low environment, E. coli do not produce the beta-galactosidase enzyme, while exposure to lactose induces a rapid production of this enzyme. Within 3-5 min, the enzyme is produced about a thousand times faster. When the lactose is removed, the production comes to a halt (Guttman et al. 2002; Lodish et al.2000; Weickert and Adhya 1993).

In 1951, Esther Lederberg discovered that E. coli can become infected with a bacteriophage that she called lambda. Research on lambda provided the definite proof that viral DNA can become integrated into the bacterial genome as a prophage and the first proof that the prophage is transmitted together with the bacterial genome to offspring (Lederberg et al. 1951; Lederberg and Lederberg 1953). A couple of years later, Morse et al. (1956) demonstrated that transduction in $E$. coli occurs via the lambda phage. This type of transduction is called specialized transduction because the lambda phage transduces the specific cluster of bacterial genes involved in galactose fermentation, and it does so only among specific members of the $E$ coli $K-12$ strain.

When $\mathrm{F}+E$. coli $(E$. coli bacteria that carry the $\mathrm{F}$ factor that enables bacterial conjugation) are crossed with $\mathrm{F}-E$. coli that carry the lambda prophage, the cross always leads to lysogenic recipients, but transduction and recombination of the lambda phage are hardly ever induced when F+ (lambda) are crossed with F- E. coli strains (Griffiths et al. 2000). Furthermore, the integration of lambda as a prophage into the bacterial chromosome of $E$. coli always occurs at a specific region, in between E. coli's gal genes involved in the galactose fermentation process and the bio genes responsible for the synthesis of biotin vitamin. Integration of lambda into E. coli therefore became a medium by which Jacob and Monod could study the expression and regulation of gal genes.

\subsection{Mobile Genetic Elements: Gene Transfer Agents, Transposons, Retrotransposons, and (Endogenous) Retroviruses}

Eukaryotic genomes contain noncoding DNA sequences (genes that do not encode for functional proteins) that include repetitive elements such as terminal repeats (that include satellite DNA), tandem repeats, and interspersed repeats. Around $98 \%$ of the human genome, for example, exists out of noncoding DNA, and about 2/3 of our genome consists of repetitive elements (de Koning et al. 2011). Especially the interspersed repeats contain (remnants of) mobile genetic elements, such as transposons and retrotransposons. Lateral exchange of mobile DNA might be the reason why there is so much repetition in organismal genomes. Bacteria also contain repetitive DNA (in the form of Insertion Sequences, Gene Transfer Agents and prophages) 
but relatively little non-coding DNA in comparison to the amounts found in eukaryotic genomes (Gil and Amparo 2012). Prophages, bacterial Insertion Sequences, and Gene Transfer Agents are also classified as mobile genetic elements.

Transposons were originally named "jumping genes" by McClintock (1950, 1953), and these "transposable elements" were first classified by Campbell et al. (1977). The concept of "mobile genetic elements" was first introduced in a book edited by Shapiro (1983) that reviewed the various means whereby genetic material can become "transposed" or relocated within and between genomes. Two other seminal review works were edited by Berg and Howe (1989) and Craig et al. (2002), and today, academic journals exist that exclusively dedicate themselves to the study of mobile genetic elements such as Mobile DNA and the Journal of Mobile Genetic Elements.

Plasmids, Gene Transfer Agents (GTAs), ribozymes (group I and II introns), and (bacterial) viruses are all examples of mobile genetic elements, and besides the latter, scholars distinguish between transposons, retrotransposons, and (endogenous) retroviruses. These are distinctive classes of genetic elements that can become the subject of "transposition" or relocation and lateral exchange within and between genomes. Scientists are currently mapping these various mobile genetic elements in order to find recurring structures, elements, patterns, and mechanisms whereby these elements are transmitted. These efforts are designated as the mobilome projects (Frost et al. 2005; Siefert 2009).

\subsubsection{Gene Transfer Agents}

Several bacteria contain Gene Transfer Agents (GTAs) in their genome. GTAs are bacteriophage-like elements that can become horizontally exchanged (Lang and Beatty 2000; Lang et al. 2012; Stanto 2007; Yen et al. 1979). GTAs present a fourth form of HGT among bacteria that works similar to transduction. The main difference with bacteriophage-induced transduction is that the GTAs appear to be defective prophages that are part of the bacterial genome. Nonetheless, upon lysis they can move location and become inserted into the genomes of recipient bacteria.

\subsubsection{Transposable Elements}

Transposons can move to another location within that same genome, or in prokaryotes, they can travel horizontally from the bacterial genome to a bacterial plasmid or vice versa, and in eukaryotes, they can travel from organellar DNA to nuclear DNA and vice versa. When transposable elements move location, it implies a form of HGT because transposition does not require division of the cell or replication of the entire genome. Jumping genes were first identified by Barbara McClintock (1942, 1950: 344-5) in chromosome 9 of maize. She called them "mutable" and "instable" genes that underlie "variegation" and "mosaicism." The position switches of jumping genes on the chromosome alter functionality of the genome 


\section{Structure of Transposable Elements}

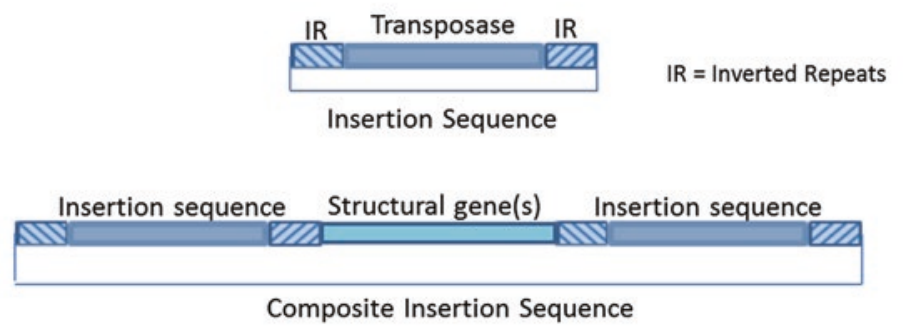

\section{Mechanisms of Lateral Transposition}

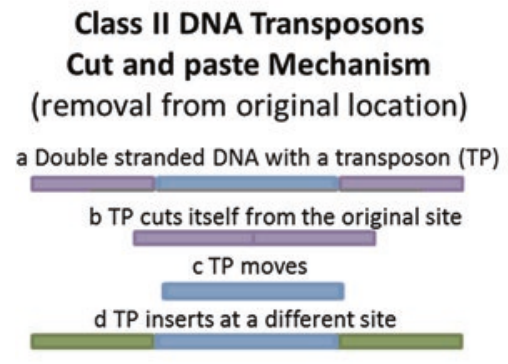

Class II DNA Transposons Cut and paste Mechanism (removal from original location)

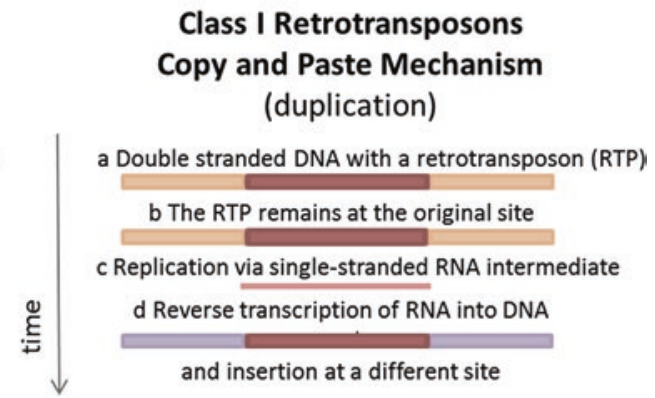

Fig. 61 Schematic of simple and composite insertion sequences. 2 Schematic of the two main modes of transposition by which DNA transposons and retrotransposons can switch position inside or between genomes

by providing a loss or introduction of new traits. More specifically, "spontaneous translocations" can lead to deletion, duplication, loss, or introduction of functions.

There exist two main classes of transposable elements: DNA transposons and retrotransposons or retroelements. DNA transposons are found in both pro- and eukaryotes, while retrotransposons are mostly found in eukaryotes (but for some exceptions see Boeke 2003). As the name implies, DNA transposons (class II) are always made up of DNA and they cut and paste themselves into genetic sequences (Finnegan 1989). Transposition thus involves a complete removal of the transposon at the original site, followed by insertion at a new site (Fig. 6(2)). When the transposition occurs within the same genome, it can lead to a loss of function at the original site as well as a loss of function at the new site, especially when insertion interrupts an existing gene sequence. When transposition occurs from the genome to a bacterial plasmid or an organellar genome, the original genome is reduced in size. Transposable elements therefore have the potential to affect functional metabolism, and they can also interfere with successful survival, reproduction, and evolution. When P elements, for example, which are transposons found in Drosophila, are transmitted from male fruit flies to females that lack them, 
their offspring becomes sterile due to the large number of mutations such a cross induces (Kidwell and Novy 1979; Spradling and Rubin 1982).

Structurally, transposons can exist as insertion elements, first identified by Bukhari et al. (1977), and Insertion Sequences (IS) can be non-composite or composite (Berg and Howe 1989). IS contain a transposase-encoding region (i.e., the genes that encode for the transposase enzyme that enables the cutting), a region that is flanked by inverted repeats that enable insertion. Besides transposase genes, compositional IS additionally carry structural genes that enable functions such as antibiotic resistance (Mahillon and Chandler 1998). Composite IS that transfer structural genes are always flanked by two non-composite IS (Fig. 6(1)). Insertion sequences were first classified by Esther Lederberg (1981), and since the 1980s, numerous different IS have been found in pro- and eukaryotic genomes (Mahillon and Chandler 1998). However, transposons make up less than $2 \%$ of the human genome.

Transposons, and also other mobile genetic elements such as plasmids, often contain integrons. Bacterial integrons were first described by Martinez and de la Cruz (1988) who reported on a "site-specific integration system" in transposon Tn21, and a year later, Stokes and Hall (1989) defined these systems as integrons. Bacterial integrons are "assembly platforms" (Mazel 2006) because they can incorporate or excise bacterial gene cassettes that encode for antibiotic resistance genes (Kovalevskaia 2002). Today, they are considered the major means whereby gram-negative bacteria acquire drug resistance (Barker et al. 1994). Sedentary bacterial integrons can also be found inside the bacterial chromosome in which case they are called chromosomal integrons (Mazel et al. 1998). These were first found in the gram-negative Vibrio cholerae, the bacterium that causes cholera, and their integron was called a "superintegron" because of its large size (Hall and Stokes 2004). There are over 50 known gene cassettes in gram-negative bacteria and five distinct classes of integrons (Barker et al. 1994; Kovalevskaia 2002; Hall 1997).

Retrotransposons (class I) are alternatively known as transposons via RNA intermediates, because they move about by copying and inserting themselves via RNA intermediates (Fig. 6(2)). The retrotransposon is not removed from the original site. Instead, it is transcribed into an RNA intermediate that subsequently moves to the new location where the RNA strand is reverse-transcribed into complementary DNA and inserted into the new site. Thus, after retrotransposition, the retrotransposable element is present in both the original site and the new site.

While DNA transposons leave gaps at the places where they cut themselves, leading to reduction in genome size and interruption of gene sequences at the insertion sites, retrotransposons enable genome growth by duplication of gene sequences.

Eukaryotic organisms contain many such gene duplications, and especially plants have huge genomes because of gene duplications. Maize genomes, for example, contain 50-70\% of retrotransposons, and the human genome is made up of $42 \%$ of retrotransposons.

Both DNA transposons and transposons via RNA intermediates enable "genetic transformation" (Spradling and Rubin 1982) of the organismal genome they belong to. In other words, they change the genetic makeup of organisms and are therefore key players in evolution. 
Retrotransposons can be further divided into LTRs, LINEs, and SINEs, a division that has to do with the length and position of the repetitive sequence. LTRs are longer than SINEs and LINEs. LTRs are Retrotransposons with Long Terminal Repeats, and they were first defined by Shine et al. (1977) in the avian sarcoma virus. LINEs are Long Interspersed Nuclear Elements first identified by Adams et al. (1980) in humans, and SINEs are Short Interspersed Nuclear Elements. The distinction between LINEs and SINEs was first made by Singer (1982). Both LTRs and LINEs use reverse transcriptase, while SINEs use RNA polymerase III for transcription and the latter make use of the more autonomous LINEs (Weiner 2002). Especially mammalian genomes, including human genomes, contain many retrotransposable LINE and SINE elements (Deininger and Batzer 2002). Some SINEs today are also classified as miniature inverted-repeat transposable elements (MITEs) (Bardaji et al. 2011; Zhang et al. 2000), which are especially numerous in flowering plants, but they are also found in insects and animals.

Especially retrotransposons violate the standard idea that information flows from DNA to RNA to proteins but not the other way round. This is because they are able to use RNA to assemble DNA. "Replicative transposition" was first described by Shapiro (1979), and the intermediate RNA is therefore sometimes called the "Shapiro intermediate."

\subsubsection{Retroviruses}

Several scholars (Wicker et al. 2007; Flavell 1981; Nelson and Hooley 2004; Ryan 2009; Temin 1980) classify retroviruses as a type of retrotransposons, namely LTRs, because retroviruses can be transformed into an LTR retrotransposon.

Retroviruses can integrate into the host's genome and become permanently transmitted to offspring. Human endogenous retroviruses are thought to make up $8 \%$ of the human genome (Cotton 2001; Nelson and Hooley 2004; Khodosevich et al. 2002; Belshaw et al. 2004).

\subsubsection{Mobile Genetic Elements and the Extended Synthesis}

It is important to note that GTAs, DNA transposons, integrons, retrotransposons, and retroviruses are container terms for numerous families. At present, scholars are in the process of identifying (the members of) these families, and they are studying the biomolecular similarities, the various taxa they belong to, and the various taxa they can transfer to in order to gain insight into the underlying mechanisms and patterns. Besides these large classes of mobile genetic elements, there are still other kinds of mobile DNA and means by which genes can become exchanged between biological individuals, including exchange via intracellular nanotubes (Dubey and Ben-Yehuda 2011) and via release of DNA-containing membrane vesicles (Mashburn-Warren and Whiteley 2006; Chiura et al. 2011). At the same time, the scholars are involved in finding similarities and differences between the various identified transposable 
elements, in order to develop new classification systems (Wicker et al. 2007). These endeavors form part of the "mobilome projects" (Frost et al. 2005). Similarities in gene frequencies and genetic organization, enzymes that mediate transposition, similar terminal repeats, functional differences of the inserted transposable elements (whether they result in genome growth, mutation, or new features), and the particular taxa wherein they are found can all function to group the various mobile genetic elements into several classes (Mahillon and Chandler 1998).

These various mobile DNA families and their members are currently listed in DNA databases and DNA banks such as ENCODE (the ENCyclopedia Of DNA Elements, The ENCODE Project Consortium 2012, and for the official Web site, see http://www.genome.gov/encode/), but to my knowledge, no scholar has so far tried to visualize these elements into taxonomies or all-encompassing mobile DNA networks or trees that map onto the current networks and trees of life.

Transposable and retrotransposable elements contradict the standard neo-Darwinian view in many ways. For one, as McClintock $(1941,1950)$ already noted, during mitotic cell regeneration (development), genes can move position, leading to chromosomal breakage or deviant but stable chromosomal rearrangements in future somatic cells. She realized that the process is not unique to maize, rather:

The same types of genetic instability appearing in the maize cultures have been described in many other organisms. The behavior of these new mutable loci in maize cannot be considered peculiar to this organism. The author believes that the mechanism underlying the phenomenon of variegation is basically the same in all organisms. (McClintock 1950: 345)

Chromosomal rearrangements can also affect the gametic cells, and when this happens, the chromosomal rearrangements can become permanently part of the progeny's genetic makeup and affect their successful survival, reproduction, and evolution. Chromosomal rearrangements were recognized by the founders of the Modern Synthesis to be one way by which genetic variation could be brought about, but for McClintock, it also implied that the location of genes on chromosomes is not fixed. Rather, genes can translocate at any moment in time, thereby significantly and rapidly impacting both ontogeny and phylogeny. McClintock also associated her research with macroevolutionary biology. In the early 1930s, she visited Goldschmidt (1940) in Germany who introduced the concepts of "macromutations" and "hopeful monsters," and jumping genes can be understood as responsible for both.

Secondly, for McClintock, translocation required an "activation" of the genes involved. That genes need to become activated implies they can be silent, and both imply differential gene expression and functionality in different periods in time. As such, she envisioned the existence of gene regulatory networks, where transposable elements function as "novel biological switches" (Cohen 1976), processes that today are studied from within evo-devo schools. McClintock (1950: 354):

changes in quantity, quality or structural organization of heterochromatic elements may well alter the kind and/or degree of particular exchanges that occur, and in this way control the chromosome organization and the kind and the relative effectiveness of genic action. There can be little question that transpositions ... occur and that the time of their occurrence in the development of a tissue is under precise control. This control is determined by the number of $\mathrm{AC}$ [activator] loci present and their organization and possibly their position in the chromosome complement. 
Thirdly, besides to evo-devo, transposition links to epigenetics. Mobile genetic elements form part of "non-encoding" gene regions. In other words, they do not encode or translate into proteins that underlie functional anatomy and metabolism of the organism. Nonetheless, mobile DNA elements impact overall genome size and genome organization, and they are known to transcribe into RNA. As such, mobile DNA can rearrange and reshape existing genomes by enhancing, silencing, or promoting gene regulatory networks, and they have been implicated in various diseases. Reverse transcription, typical of retrotransposons, is a prototypical example of "epigenetic change" defined as post-translational or non-translational changes induced in the genetic code. Of course, many (retro-) transposable elements carry the genes required for their own copy/cut and pasting, but such genetic information is autonomous of the functional parts of the genome that underlies bodily form and functional metabolism. More specifically, mobile genetic elements underlie post-transcriptional RNA silencing/RNA interference/ quelling (Fire et al. 1998), as well as chromatin remodeling and DNA methylation. These are ways by which the genetic code can become permanently modified during ontogeny. Such ontogenetic modifications can become stable, and as such, they can become transmitted to future generations. The fact that many mobile genetic elements induce such changes implies that these epigenetic traits themselves are interchangeable and thus mobile between organisms (for a discussion, see Galun 2003). Transposons can be linked to pathogenicity and genome reduction, while retrotransposons potentially introduce genetic variation and innovation. Because transposons play an important part in genome size, they can causally influence evolution, by interferring with chromosomal compatibility.

Fourthly, because (retro-) transposable elements can have developmental and evolutionary functionality, it makes scholars question the existence of "Junk DNA" (Ohno 1972). Mobile genetic elements form part of the noncoding regions of DNA, and these noncoding regions were first designated as "Junk DNA" by Ohno (1972). Ohno is one of the molecular geneticists that theorized that gene duplications can be understood as "mutations" that contribute creatively to the evolutionary process (Ohno 1970). The idea that there exists "Junk DNA" in turn made scholars like Dawkins (1976) introduce the notion of "selfish replicators," themes that became repeated in exo- and astrobiological research schools as well as in research on transposable elements. In an April 1980 issue of the journal Nature, for example, Doolittle and Sapienza (1980) characterized transposable elements in particular and Junk DNA in general as "selfish genes," and in that same issue, Orgel and Crick characterized selfish DNA as the "ultimate parasite." Since then, many potential functions have been attributed to these "Junk" regions. According to Gregory (2007):

Those who complain about a supposed unilateral neglect of potential functions for noncoding DNA simply have been reading the wrong literature. In fact, quite a lengthy list of proposed functions for non-coding DNA could be compiled .... Examples include buffering against mutations ... or retroviruses ... or fluctuations in intracellular solute concentrations ..., serving as binding sites for regulatory molecules ..., facilitating recombination ..., inhibiting recombination ..., influencing gene expression ..., increasing evolutionary flexibility ..., maintaining chromosome structure and behavior ..., coordinating genome function ..., and providing multiple copies of genes to be recruited when needed... . 
According to the scholars involved in the ENCODE project, over $70 \%$ of the noncoding DNA regions found in the human genome are transcribed and targeted by transcription factors of regulatory genes. In other words, according to these scholars, though they are not involved in the formation of anatomical form, there exists biochemical functionality (for a discussion, see Kellis et al. 2014).

Fifthly, because organisms can do without many of the inserted elements, because they are exchanged between various organisms, and because the acquisition of transposable elements has the potential to cause evolutionary innovation, several scholars understand especially LINEs and SINEs (Oshima and Okada (2005), as well as retroviruses and endogenous retroviruses (or LTRs) as symbionts (Ryan 2009; Villarreal 2008).

\section{Conclusion}

While HGT has only been recognized from the 1990s onward, the historical origin of lateral gene transfer mechanisms tracks back to the early twentieth century and converges with ongoing research on intracellular and hereditary symbiosis as well as the advent of the biomedical sciences and research on abiogenesis. For years now, vaccination therapies have relied on artificially induced symbiosis whereby foreign cells are brought together to create immunity. Any and all therapeutic cures proposed by medicinal doctors to treat disease, be they the abstraction and administration of antibiotics, or the introduction of chemotherapeutic agents, is always based upon horizontal exchange of substances during ontogeny. These therapies provide hope to eradicate disease, at minimum during the individual's life time, and preferably during all future generations to come (which, for example, was successfully induced with the worldwide eradication of the smallpox virus).

The discoveries of bacterial transformation, phage-mediated transduction, bacterial conjugation, and mobile genetic elements furthermore converge with the major milestones of neo-Darwinian theory. Artificially induced HGT of phages into bacterial cells, for example, has been the major tool whereby scholars have performed genetic linkage studies whereby they have come to learn how genes underlie metabolism and how metabolism underlies anatomical form. Yet, symbiogenesis and HGT, though known for so long and foundational for some of the major neo-Darwinian and biomedical claims, have hardly made it into the standard textbooks, which brings to light an almost schizophrenic ambivalence.

Why have these data served to proof neo-Darwinian claims, but why have the incoming data and applications of transformation, transduction, and conjugation not themselves been considered as instances of evolution? One of the major stumbling blocks has been the neo-Darwinian divide between ontogeny and phylogeny. Another is the neo-Darwinian demand to understand evolution as a familial pedigree, where parental species give evolutionary existence to daughter species. In hindsight, this might have been too anthropo- or animal centric. In recent years, scholars have been trying to map non-genealogical evolutionary relations between various organisms and between 
various species. The acquisition of foreign DNA through lateral gene transfer undoes the rigid demand to think about evolution in terms of common descent with modification. Instead, modification of species, and exchange of foreign DNA, can occur between distantly and non-related species. Exchange can even occur between living organisms and viral genetic agents which have traditionally been conceived as non-living beings.

Evolutionary theory no longer exclusively encompasses the study of biogenesis, or how existing life brings forth new life. The recent pleas to include the abiotic environment into evolutionary iconography, and to cartography the various metabolic pathways that have evolved, equally open up new and inspiring ways to think about how evolution brings forth patterns that extend the "germ line."

The biggest "take home" message of HGT research, however, is that genetic material is anything but a "frozen accident." After the double-helix was discovered, Crick (1968), and following physicists such as Erwin Schrödinger, wrote a very famous paper wherein he characterized DNA as such. DNA was "frozen" because it was assumed to be a very rigid structure that only occasionally underwent genetic modification by mutations which were merely understood as random copying errors. The specific structures of the DNA base pairs and the rigid translation machinery whereby codons are translated into amino acids made scholars assume that the genetic code was a "frozen" structure. The idea that the specific structure of DNA was an "accident" resulted from theories as they were introduced by Manfred Eigen, who characterized the formation of the double helix as the result of hypercyclic organization which he characterized as a "once forever" event (for a discussion, see Gontier 2005).

Besides genes, the genome was furthermore argued to consist of round and about $75 \%$ of "Junk DNA" that served no purpose. Rather it was just the "fallout," as it were, the remains of the formation of the "frozen accident" that, because of the presumed rigid DNA-structure, could not become eradicated. At best, they served "selfish DNA" theory, where the Junk DNA was argued to have no other purpose than to selfishly replicate itself inside the vehicles it rides. When Dawkins (1976) introduced his selfish gene theory, he was battling Ernst Mayr's idea of the "unity of the genotype." He was a true visionary when he, as one of the first, started to defragment the genome into multiple replicators that each can be studied in and of itself. However, such defragmentation has brought to light that even the smallest DNA fragments are anything but passive elements waiting to become replicated.

Instead, our genome consists of numerous genetic elements that portray an enormous flexibility and mobility. Today, we know that these regions, formerly designated as Junk, contain these fascinating mobile genetic elements that include the viral particles, transposons and retrotransposons, integrons, etc. The means by which genes can be moved and the means whereby they cut and copy themselves within the genome and across genomes demonstrate a remarkable form of flexibility. How much of this flexibility is non-accidental remains an open question. But it is becoming more and more evident that DNA not merely "moves" out of selfish "needs" for propagation. Many mutualistic benefits can be identified to result from HGT, including DNA repair, genome growth, and acquisition of novel functions.

This in turn raises interesting questions on biochemical communication. The mobile elements possess the locks and keys to the cells and genomes they exit or 
enter, and our bodies equally possess our immunizing recognition systems that demonstrate an intricate coevolutionary and symbiotically evolved biochemical communication system.

HGT also demonstrates that such genetic flexibility comes at an incredibly fast pace. When antibiotics became administered, in less then 10 years did the first instances of resistance and horizontal spread of resistance become reported. Chromosomal breakages, epigenetic changes, and gene loss or acquisition due to transposition can at once, and even within an individual's life span, alter their genetic endowment.

Many of these ontogenetically acquired changes can furthermore be passed on to future generations, and besides natural selection, we need to bring in symbiogenesis theory, evolutionary developmental theory, and punctuated equilibria theory to try and make sense of it all. Gould has long critiqued the Modern Synthesis for its adherence to only one evolutionary mechanism. Darwin was a pluralist, and punctuated equilibria, for example, already demonstrated that abiotic factors can have a causal influence on the further evolution of life, as does development. Gould therefore pleaded for process pluralism, and in recent years, Bapteste and Doolittle have added the requirement of pattern pluralism. The study of reticulate evolution brings to light a new evolutionary pattern whereby life evolves, a pattern that takes on the shape of a web or net of life. To make sense of both this pattern and process pluralism, however, we also need epistemic pluralism. We need to find a way to extend the evolutionary synthesis into an evolutionary framework that enables us to conceptualize the numerous evolutionary mechanisms whereby life evolves.

Acknowledgments This work was written with the support of the Portuguese Fund for Scientific Research (grant ID SFRH/BPD/89195/2012 and project number UID/FIL/00678/2013) and the John Templeton Foundation (grant ID 36288).

\section{Timeline}

1717 Mary Wortley Montagu introduces "variolation," an immunizing technique against smallpox (Variola)

1798 Edward Jenner injects cowpox as an immunizing technique against smallpox (Variola). His work avalanches a series of inoculation experiments that underlie vaccination therapy

1809 Jean Baptiste Chevalier de Lamarck publishes his Philosophie Zoologique

1817-1828 The fields of embryology, epigenetics, and evo-devo take off with the works of Heinz Christian Pander, Karl Ernst Ritter von Baer, and Edler von Huthorn

1837/1838 Darwin draws the "I think" diagram in his Notebook B

$1838 \quad$ Matthias Schleiden contends that all plants are made up of cells

1839 Theodor Schwan declares that all animals are made up of cells

1848 Wilhelm Hofmeister describes mitosis

1855 Rudolf Virchow declares that all cells come from pre-existing cells 
1859 Darwin publishes his Origin of Species and uses the "tree of life" metaphor in Chap. 4. The book contains a hypothetical branching diagram that illustrates how species gradually diverge through time by means of natural selection

1861 Heinrich Anton de Bary identifies microorganisms as the cause of plant diseases, and he later introduces the concept of symbiosis

1866 Gregor Mendel introduces his laws of inheritance

1866 Ernst Haeckel introduces the first non-hypothetical "Tree of Life"

1868 Johannes Friedrich Miesher names a substance inside the nucleus of cells "nuclein" (DNA)

1870 Thomas Henry Huxley distinguishes biogenesis from abiogenesis and denies abiogenesis (alternatively known as spontaneous generation)

1873/1875 Pierre Joseph van Beneden identifies parasitic microorganisms as the cause of animal diseases and distinguishes between commensalism, parasitism, and mutualism

1875 Ferdinand Cohn introduces a first classification of bacteria

1876 Robert Koch identifies the Anthrax bacillus responsible for "Milzbrand-Krankheit" (anthrax disease) and proves earlier theoretical versions of the germ theory of disease to be true

1877 Paul Ehrlich starts his career by developing new techniques to color bacteria. These techniques will enable him to specify the various types of blood cells there exist, research that will found the study of both serology and immunology

1878 Louis Pasteur's work on the germ theory of disease is read before the French Academy of Sciences

1879 Timothy Lewis identifies microorganisms inside the bloodstream of humans and links them to disease

1880 Charles Louis Alphonse Laveran identifies flagella-like motile unicellular organisms that he identifies as causal agents of malaria

1882 Ilya Ilyich Mechnikov observes what he later calls phagocytosis: cell eating. Phagocytosis is crucial to understand immunity as well as primary, secondary, and tertiary symbiosis

1884 Robert Koch publishes his etiology of tuberculosis that proves that the tubercle bacillus is the disease-causing agent of tuberculosis

1884 Hans Christian Joachim Gram develops the Gram stain technique that enables to differentiate between "gram-negative" and "gram-positive" bacteria

1885 Auguste Weismann develops his "transmutation hypothesis." The work is foundational for the "Weismann barrier" that puts a halt to (neo-)Lamarckian theories

1886 Theodor Escherich identifies a "bacterium coli commune" that resides in the human gut $(E$. coli)

1886 D.E. Salmon and Theobald Smith improve vaccination therapies by injecting whole heat-killed cells of virulent strains

1886 Adolf Mayer describes the tobacco mosaic disease 
1888 The Pasteur Institute is founded in France

1890 The Cold Spring Harbor Laboratory is founded in Brooklyn, New York

1891 The Robert Koch Institute is founded in Germany

$1891 \quad$ Paul Ehrlich discovers antibodies

1892 Dmitri Iwanowski demonstrates that the tobacco mosaic disease is caused by a non-bacterial infectious agent

1898 Martinus Beijerinck defines the agent responsible for the tobacco mosaic disease as a virus which he characterizes as a "living and fluid infectious agent"

1900 Mendel's hereditary laws are (re)discovered by Hugo de Vries, Carl Correns, and Erich von Tschermak

1902/1910 Fred Neufeld classifies Pneumococci into three different types

1905 Constantin Mehrezkowsky introduces a double-origin theory of life, a view he illustrates with a reticulate "tree of life" in 1910

1909 Theodor Boveri and Walter Sutton introduce the chromosome theory

1909 Wilhelm Johannsen distinguishes between the genotype and phenotype

1912 Friedrich Karl von Faber introduces the notion of "erbliche Zusammenleben" (hereditary symbiosis)

1915 Hermann Reinheimer introduces the metaphor of the "web of life"

1915 Frederick Twort discovers bacterial lysis and assumes it is induced by viral agents that infect bacteria

1917 Félix d'Herelle cultures viruses that infect bacteria and calls them "bacteriophages"

$1928 \quad$ Frederick Griffith reports on bacterial transformation

1929 Alexander Fleming reports that the mold Penicillium notatum undertakes "antibacterial action" against gram-positive microorganisms

1931 Ernst Ruska and Max Knoll build the first electron microscopes

1932 Julius Petrie introduces serological typing

1938 Warren Weaver coins the term "molecular biology"

1941 George Beadle and Edward Tatum demonstrate that protein synthesis as well as the function of enzymes is controlled by genes and they introduce the "one gene-one enzyme theory" (a term coined by Norman Horowitz)

1942 Conrad Waddington coins the term "epigenetics"

1942 Julian Huxley characterizes the late nineteenth century as the "eclipse of Darwinism"

1943 Salvador Luria and Max Delbrück demonstrate that bacteria evolve according to Darwinian principles (they "mutate" randomly)

1944 Oswald Avery, Colin MacLeod, and Maclyn McCarthy confirm that bacteria can transform and they identify DNA as the transforming principle

1944 Barbra McClintock discovers "jumping genes," what we now call "transposons" or "mobile genetic elements" in maize 
1944 Albert Schatz isolates the antibiotic streptomycin from Streptomyces griseus at Selman Waksman's laboratory which becomes administered against tuberculosis

1946 Joshua Lederberg and Edward Tatum report on bacterial conjugation in the $E$. coli $\mathrm{K}-12$ strain

1950/1953 André Lwoff and Antoinette Gutmann distinguish between the lysogenic and lytic phases of bacteriophages and introduce the concept of "prophage"

1950 Antibiotics such as streptomycin, penicillin, and chloramphenicol are massively produced and administered

1951 Victor Freeman reports on HGT from a bacteriophage to C. diphtheria

1951 Esther Lederberg discovers that E. coli can become infected with a bacteriophage that she calls lambda

1952 Joshua Lederberg, Luigi-Luca Cavalli Sforza, and Esther Lederberg, and independently William Hayes, report on the Fertility factor in E. coli that enables bacterial conjugation

1952 Norton Zinder and Joshua Lederberg report on phage-mediated bacterial transduction

1952 Joshua Lederberg introduces the plasmid concept to designate all extrachromosomal DNA by which he intends to include mitochondrial and chloroplast DNA (still a theoretical notion) and viral prophages, and he applies the notion of "hereditary symbiosis" as well as "infective heredity" to the phenomena of bacterial transformation, phage-mediated transduction, and bacterial conjugation

1952 Alfred Hershey and Martha Chase perform the Hershey-Chase experiments with bacteriophage $\mathrm{T} 2$ and the $E$. coli bacterium and confirm that DNA, and not proteins, carries hereditary information

1953 X-ray crystallography of DNA performed by Rosalind Franklin leads Francis Crick, Maurice Wilkins, and James Watson to describe the double-helical structure of DNA

1955 Norton Zinder demonstrates transduction of antibiotic resistance genes

1959-1963 Japanese scholars Kunitaro Ochia, Tomoichiro Akiba, and Tsutomu Watanabe report on bacteria that have acquired resistance genes against antibiotics in natural settings and identify bacterial conjugation as the likely mode of transfer

1959 Arthur Pardee, François Jacob, and Jacques Monod (1959) publish the "PaJaMo" paper that demonstrates protein regulation of gene expression, or gene regulatory networks. They base their work on their studies of galactosidase fermentation in E. coli

1963 Linus Pauling and Émile Zuckerkandl map the changes in hemoglobin polypeptide chains of different mammalian species and find 
that "semantides": "DNA, RNA, and polypeptides" lend themselves for comparative bimolecular analysis

1969/1970 Stanley Cohen, Annie Chang, and Leslie Hsu demonstrate that E. coli can take up plasmids carrying antibiotic resistance genes ( $\mathrm{R}$ factors)

1970 Howard Temin and S. Mizutani, and independently David Baltimore, discover reverse transcriptase

1972 Susumo Ohno introduces the concept of "Junk DNA"

1976 Richard Dawkins introduces the "selfish gene" theory

1977 Frederic Sanger sequences the first entire genome of a bacteriophage

1977 Carl Woese and George Fox divide prokaryotes into Archaebacteria and Eubacteria which they define as "urkingdoms" or "primary kingdoms"

1977 Bukharo, Shapiro, and Adhya identify insertion sequences

1977 Shine and colleagues identify long terminal repeats (LTRs) in the genome of the avian sarcoma virus

1977 Allan Campbell and colleagues provide a first nomenclature of transposable elements in prokaryotes

1978 Whittaker and Margulis introduce a 5-kingdom classification of life that understands symbiogenesis as the defining mechanism that separates prokaryotes (Monera) from all 4 eukaryotic kingdoms, and in subsequent years, Margulis introduces new, reticulate evolutionary iconography

$1979 \quad$ Variola is declared eradicated

1979 James Shapiro describes the RNA intermediate stage of retrotransposons

1979 Yen, Hu, and Marrs (1979, Marrs 1974) report on "nucleoprotein particles that act as vectors of genetic exchange," i.e., GTAs in Rhodopseudomonas capsulata (today called Rhodobacter capsulatus)

1980 Alex Champion uses the concepts of "HGT" and "reticulate evolution" to understand the evolution of Pseudomonas fluorescens

1981 Joachim Messing develops the shotgun DNA sequencing technique which enables the sequencing of longer stretches of DNA up to whole genomes

1981 Esther Lederberg provides a classification system for insertion sequences

1982 Maxine Singer distinguishes between Short Interspersed Nuclear Elements (SINEs) and Long Interspersed Nuclear Elements (LINEs)

1983 Kary Mullis introduces the polymerase chain reaction (PCR) technique

1983 James Shapiro edits a first anthology on "mobile genetic elements"

1984 Michael Syvänen introduces the notion of "cross-species gene exchange"

1989 Peter Gogarten and colleagues introduce ATPase-based phylogenetic reconstructions of the roots of the tree of life and suggest that these genes were acquired by "HGT" 
1989 Jack Heinemann and George Sprague demonstrate that "Bacterial conjugative plasmids mobilize DNA transfer between bacteria and yeast (Saccharomyces cerevisiae)"

1989 The American Society for Microbiology publishes their first anthology on mobile DNA, the work is edited by Douglas Berg and Martha Howe

1989 Douglas Berg and Martha Howe differentiate between compositional and non-compositional insertion sequences

1989 Stokes and Hall differentiate integrons as "a novel family of potentially mobile DNA elements encoding site-specific gene integration functions"

1990 Hacker and coworkers introduce the concept of pathogenicity islands to designate specific regions in the genome of bacterial pathogens that are absent in non-pathogenic bacteria

1990 Woese, Kandler, and Wheelis introduce the three-domain classification of life (Archaea, Bacteria, and Eukaryota)

1994 The Tree of Life Web Project (ToL) commences and goes online in 1996

1995 The complete genome of Haemophilus influenza is sequenced by Craig Venter, Hamilton O. Smith, and Claire Fraser at the Institute for Genomic Research

1998 Didier Mazel and colleagues discover superintegrons in Vibrio cholerae bacteria

1998 Jo Handelsman and colleagues introduce the term "metagenomics" to designate biochemical techniques used to identify the genetic constitution of unidentified soil bacteria

1999 Ford W. Doolittle introduces a hypothetical reticulate image and the metaphor of a "web of life" to visualize and conceptualize the massive HGT that occurs across all three domains of life

1999 Eisterling and colleagues report on a "bacteriophage-like particle," the "voltae transfer agent," of Methanococcus voltae PS. This GTA enables transductions between members of the bacterial strain

2000 Andrew S. Lang and J.T. Beatty report on a GTA in the purple nonsulfur bacterium Rhodobacter capsulatus

2000 Peter Gogarten introduces the metaphor of a "net" and "network" of life

2001/2002 The American National Science Foundation launches the AToLAssembling the Tree of Life Project

2002 The American Society for Microbiology publishes their second anthology on mobile DNA, which is edited by Nancy L. Craig, Robert Craigie, Martin Gellert, and Alan M. Lambowitz

2003 The barcoding technique is introduced by Paul Hebert and colleagues

2004 Maria Rivera and James Lake introduce the "ring of life"

2004 The American Journal of Botany dedicated a special issue to the tree of life of plants 
2005 In an article for Scientific American, Ford Doolittle expands his reticulate evolutionary image in order to include the symbiogenetic acquisition of chloroplasts and mitochondria

2005 Fan Ge, Li-San Wang, and Junhyong Kim introduce the metaphor of a "cobweb" of life

2005 The Tree Thinking Group goes online

2006 Bork's team publishes their circular tree of life (Ciccarelli et al. 2006) in Science and launches the online iTOL project

2009 The New Scientist features a reticulate tree of life image on their January 21st cover and titles it "Darwin was wrong: Cutting down the tree of life." Daniel Dennett, Jerry Coyne, Richard Dawkins, and Paul Meyers argue that the cover feeds into creationism

2009 Tal Dagan and William Martin introduce networks that depict actual horizontal as well as vertical exchange between distinct microbial lineages

2009 The Philosophical Transactions of the Royal Society, B: Biological Sciences features a theme issue on "The network of life: genome beginnings and evolution"

2010 Luis Villarreal and Günter Witzany introduce a hypothetical diagram that illustrates the viral origin of life as well as the colonization of all three domains of life by viral agents

2010 The journal Biology and Philosophy features a special issue on the tree of life

2011 The journal Research in Microbiology dedicates a special issue to "Archaea and the tree of life"

2011 Biology Direct publishes an issue titled "Beyond the Tree of Life"

2014 The American National Science Foundation launches the GoLife (Genealogy of Life) project

2014 The Journal of Ecology features a special issue on "The tree of life in ecosystems: evolution of plant effects on carbon and nutrient cycling"

Note: This timeline is based upon the timeline provided by the American Society for Microbiology (ASM) available at http://www.asm.org/index.php/choma3/71membership/archives/7852-significant-events-in-microbiology-since-1861; the Genome News Network site at http://www.genomenewsnetwork.org/resources/ timeline; as well as own work.

\section{References}

Adams JW, Kaufman RE, Kretschmer PJ, Harrison M, Nienhuis AW (1980) A family of long reiterated DNA sequences, one copy of which is next to the human beta globin gene. Nucleic Acids Res 8(24):6113. doi:10.1093/nar/8.24.6113

Akamatsu T, Taguchi H (2001) Incorporation of the whole chromosomal DNA in protoplast lysates into competent cells of Bacillus subtilis. Biosci Biotechnol Biochem 65(4):823-829. doi:10.1271/bbb.65.823 
Akiba T, Koyama K, Ishiki Y, Kimura S, Fukushima T (1960) On the mechanism of the development of multiple-drug-resistant clones of Shigella. Jpn J Microbiol 4(2):219-227. doi:10.1111/j.1348-0421.1960.tb00170.x

Ambler P, Meyer T, Kamen MD (1979) Anomalies in amino acid sequences of small cytochromes $\mathrm{c}$ and cytochromes $\mathrm{c}^{\prime}$ from two species of purple photosynthetic bacteria. Nature 278:661-662

Andam CP, Williams D, Gogarten JP (2010) Natural taxonomy in light of horizontal gene transfer. Biol Phil 25(4):589-602

Anderson ES (1968) The ecology of transferable drug resistance in the enterobacteria. Annu Rev Microbiol 22:131-180

Andersson DI, Hughes D (2010) Antibiotic resistance and its cost: is it possible to reverse resistance? Nat Rev Microbiol 8:260-271. doi:10.1038/nrmicro2319

Arnold ML (2008) Reticulate evolution and humans: origins and ecology. Oxford University Press, New York

Avery OT, Macleod CM, McCarty M (1944) Studies on the chemical nature of the substance inducing transformation of pneumonococcal types. Induction of transformation by a deoxyribo-nucleic acid fraction isolated from pnuemococcus type III. J Exp Med 79:137-157

Bachmann BJ (1972) Pedigrees of some mutant strains of Escherichia coli K-12. Bacteriological Rev 36(4):525-557

Bapteste E, Susko E, Leigh J, MacLeod D, Charlebois RL, Doolittle WF (2005) Do orthologous gene phylogenies really support tree-thinking? Evol Biol 5:33

Bapteste E et al (2009) Prokaryotic evolution and the tree of life are two different things. Biology Direct 4:34

Bardaji L, Añorga M, Jackson RW, Martínez-Bilbao A, Yanguas N, Murillo J (2011) Miniature transposable sequences are frequently mobilized in the bacterial plant pathogen Pseudomonas syringae. PLoS ONE 6(10):e25773

Barker A, Clark CA, Manning PA (1994) Identification of VCR, a repeated sequence associated with a locus encoding a hemag glutinin in Vibrio cholerae O1. J Bacteriol 176:5450-5458

Behring E, Kitasato S (1890) Ueber das Zustandekommen der Diphtherie-Immunitat und der Tetanus-Immunitat bei Thieren. Deutsche medizinsche Wochenschrift 16:1113-1114

Beijerinck MW (1898) Über ein Contagium vivum fluidum als Ursache der Fleckenkrankheit der Tabaksblätter. Verhandelingen der Koninklijke academie van Wetenschappen te Amsterdam 65:1-22

Belshaw R, Pereira V, Katzourakis A, Talbot G, Paces J, Burt A, Tristem M (2004) Long-term reinfection of the human genome by endogenous retroviruses. PNAS 101(14):4894-4899. doi:10.1073/pnas.0307800101

Berg DE, Howe MM (eds) (1989) Mobile DNA. American Society for Microbiology, Washington DC

Boeke JD (2003) The unusual phylogenetic distribution of retrotransposons: A hypothesis. Genome Res 13:1975-1983

Buchner P (1921) Tier und Pflanze in intrazellularer Symbiose. Berlin

Bukhari AI, Shapiro JA, Adhya SL (1977) DNA insertion elements, plasmids, and episomes. Cold Spring Harbor Laboratory: Cold Spring, Harbor NY

Burnet FM (1934) The bacteriophages. Biol Revs Cambridge Phil Soc 9:332-350

Busslinger M, Rusconi S, Birnstiel ML (1982) An unusual evolutionary behavior of a sea urchin histone gene cluster. EMBO J 1(1):27

Case CL, Chung K (1997) Montagu and Jenner: the campaign against smallpox. SIM News 47(2):58-60

Cavalli Sforza LL (1950) La sessualita new batteri. Boll Ist Sierotera Milano 29:281-289

Champion AB et al (1980) Evolution in Pseudomonas fluorescens. J Gen Microbiol 120(2):485-511

Chen I, Dubnau D (2004) DNA uptake during bacterial transformation. Nat Rev Microbiol 2(3):241-249. doi:10.1038/nrmicro844

Chen K, Pachter L (2005) Bioinformatics for whole-genome shotgun sequencing of microbial communities. PLoS Comput Biol 1(2):e24. doi:10.1371/journal.pcbi.0010024 
Chiura HX, Kogure K, Hagemann S, Ellinger A, Velimirov B (2011) Evidence for particleinduced horizontal gene transfer and serial transduction between bacteria. FEMS Microbiol Ecol 76:576-591

Ciccarelli FD, Doerks T, von Mering C, Creevey CJ, Snel B, Bork P (2006) Toward automatic reconstruction of a highly resolved tree of life. Science 311:1283-1287

Cohen SN (1976) Transposable genetic elements and plasmid evolution. Nature 263:731-738. doi:10.1038/263731a0

Cohen SN, Miller CA (1969) Multiple molecular species of circular R-factor DNA isolated from Escherichia coli. Nature 224:1273-1277

Cohen SN, Miller CA (1970) Molecular nature of R-factors isolated from Proteus mirabilis and Escherichia coli. J Mol Biol 50(3):671-687

Cohen S, Chang A, Hsu L (1972) Nonchromosomal antibiotic resistance in bacteria: genetic transformation of Escherichia coli by R-factor DNA. PNAS 69(8):2110-2114. doi:10.107 3/pnas.69.8.2110

Cohn FJ (1875) Untersuchungen über Bakterien. Beitraege zur Biologie der Planzen 1:127-222

Campbell A et al (1977) Nomenclature of transposable elements in prokaryotes, DNA insertion elements, plasmids, and episomes. Cold Spring Harbor Laboratories, New York pp 15-22; also, 1979, Gene, 5, pp 197-206

Cornelissen JH, Cornwell WK (2014) The tree of life in ecosystems: evolution of plant effects on carbon and nutrient cycling. J Ecol 269-274 doi:10.1111/1365-2745.12217

Cotton J (2001) Retroviruses from retrotransposons. Genome Biol 2(2):6

Coughter JP, Stewart GJ (1989) Genetic exchange in the environment. Antonie Van Leeuwenhoek $55(1): 15-22$

Cowles HC (1915) Hereditary symbiosis. Bot Gaz 59(1):61-63

Craig NL, Craigie R, Gellert M, Lambowitz AM (eds) (2002) Mobile DNA II. ASM Press, Washington

Crick F (1968) The origin of the genetic code. J Mol Biol 38:367-379

Dagan T, Martin W (2006) The tree of one percent. Genome Biol 7:118. doi:10.1186 /gb-2006-7-10-118

Dagan T, Martin W (2009) Getting a better picture of microbial evolution en route to a network of genomes. Phil Trans R Soc B 364:2187-2196

Daniels SP et al (1990) Evidence for horizontal transmission of the P transposable element between Drosophila species. Genetics 124:339-335

Darwin C (1837-1838) Notebook B: [Transmutation of species (1837-1838)]. CUL-DAR121transcribed by Kees Rookmaaker. Darwin Online. http://darwin-online.org.uk

Darwin C (1859) On the origin of species. Murray, London

Dawkins R (1976) The selfish gene. Oxford Univ Press, London

De Bary HA (1861) Die gegenwärtig herrschende Kartoffelkrankheit, ihre Ursache und ihre Verhütung: Eine pflanzenphysiologische Untersuchung in allgemein verständlicher Form dargestellt. Leipzig: A. Förstersche Buchhandlung

de Koning AP, Gu W, Castoe TA, Batzer MA, Pollock DD (2011) Repetitive elements may comprise over two-thirds of the human genome. PLoS Genet 7:e1002384. doi:10.1371/ journal.pgen. 1002384

de Magalhães J, Finch C, Janssens G (2010) Next-generation sequencing in aging research: emerging applications, problems, pitfalls and possible solutions. Ageing Res Rev 9(3):315323. doi:10.1016/j.arr.2009.10.006

Deininger PL, Batzer MA (2002) Mammalian retroelements. Genome Res 12(10):1455-1465. doi:10.1101/gr.282402

Dennett D, Coyne J, Dawkins R, Myers P (2009) Darwin was right. New Sci 201(2696):25

D'Herelle F (1917) Sur un microbe invisible antagoniste des bacilles dysentériques. CR Acad Sci Paris 165:373-375. doi:10.1098/rstb.2009.0040

Doolittle WF (1999) Phylogenetic classification and the universal tree. Science 284:2124-2128. doi:10.1126/science.284.5423.2124 
Doolittle FW (2005) If the tree of life fell, would we recognize the sound? In: Sapp J (ed) Microbial phylogeny and evolution: concepts and controversies. Oxford University Press, New York, pp 119-133

Doolittle WF (2009) The practice of classification and the theory of evolution, and what the demise of Charles Darwin's tree of life hypothesis means for both of them. Proc Natl Acad Sci USA. doi:10.1098/rstb.2009.0032

Doolittle WF, Bapteste E (2007) Pattern pluralism and the tree of life hypothesis. Proc Natl Acad Sci USA 104:2043-2049. doi:10.1073/pnas.0610699104

Doolittle WF, Sapienza C (1980) Selfish genes, the phenotype paradigm and genome evolution. Nature 284(5757):601-603. doi:10.1038/284601a0

Doolittle WF et al (1990) A naturally occurring horizontal gene transfer from a eukaryote to a prokaryote. J Mol Evol 31:383-388

Downie AW (1972) Pneumococcal transformation-a backward view: fourth Griffith memorial lecture. J Gen Microbiol 73(1):1-11. doi:10.1099/00221287-73-1-1

Dubey GP, Ben-Yehuda S (2011) Intercellular nanotubes mediate bacterial communication. Cell 144:590-600

Dubnau D (1999) DNA uptake in bacteria. Annu Rev Microbiol 53(1):217-244. doi:10.1146/annurev.micro.53.1.217

Ehrlich P (1877) Beiträge zur Kenntniss der Anilinfärbungen und ihren Verwendung in der mikroskopischen Technik.In: Schultze M (ed) Archiv für Mikroskopische Anatomie Bd 13. Valetta St. George, Bonn \& W. Waldeyer, Strassburg, pp 263-277

Ehrlich P (1879a) Beiträge zur Kenntniss der granulirten Bindegewebszellen und der eosinophilen Leukocythen. Archiv fuer Anatomie und Physiologie, Physiologische Abteilung, pp 166-169

Ehrlich P (1879b) Ueber die specifischen Granulationen des Blutes. Archiv fuer Anatomie und Physiologie, Physiologische Abteilung, pp 571-579

Ehrlich P (1892a) Bemerkungen über die Immunität durch Vererbung und Säugung. Dtsch Med Wochenschr 18:511

Ehrlich P (1892b) Ueber Immunität durch Vererbung und Säugung. Zeitschrift für Hygiene und Infektionskrankheiten, medizinische Mikrobiologie, Immunologie und Virologie 12:183-203

Ehrlich P (1898) Ueber den Zusammenhang von chemischer Constitution und Wirkung. Münchener medizinische Wochenschrift 1654-1655

Ehrlich P (1900) Cellularbiologische Betrachtungen über Immunität. Bericht der Senckenbergischen Naturforschenden Gesellschaft in Frankfurt am Main 147-150

Ehrlich P, Morgenroth J (1902) Die Seitenkettentheorie der Immunität. Anleitung zu hygienischen Untersuchungen: nach den im Hygienischen Institut der königl. Ludwig-MaximiliansUniversität zu München üblichen Methoden zusammengestellt 3. Aufl 381-394

Eisen JA (2007) Environmental shotgun sequencing: its potential and challenges for studying the hidden world of microbes. PLoS Biol 5(3):e82. doi:10.1371/journal.pbio.0050082

Eldredge N, Gould SJ (1972) Punctuated equilibria: an alternative to phyletic gradualism. In Schopf TJM (ed) Models in paleobiology. Freeman. Cooper and Co, New York, pp 82-115

Engelmoer DJ, Rozen DE (2011) Competence increases survival during stress in Streptococcus pneumoniae. Evolution 65(12):3475-3485. doi:10.1111/j.1558-5646.2011.01402.x

Finkel SE, Kolter R (2001) DNA as a nutrient: novel role for bacterial competence gene homologs. J Bacteriol 183(21):6288-6293. doi:10.1128/JB.183.21.6288-6293.2001

Finnegan DJ (1989) Eukaryotic transposable elements and genome evolution. Trends Genet 5:103-107

Fire A, Xu S, Montgomery MK, Kostas SA, Driver SE, Mello CC (1998) Potent and specific genetic interference by double-stranded RNA in Caenorhabditis elegans. Nature 391(6669):806-811

Flavell AJ (1981) Did retroviruses evolve from transposable elements? Nature 289:10-11

Fournier GP, Dick AA, Williams D, Gogarten JP (2011) Evolution of the Archaea: emerging views on origins and phylogeny. Res Microbiol 162(1):92-98 
Fox GCA et al (1980) The phylogeny of prokaryotes. Science 209(4455):457-463. doi:10.1126/ science.6771870

Freeman VJ (1951) Studies on the virulence of bacteriophage-infected strains of Corynebacterium diphtheriae. J Bacter 61(6):675-688

Galun E 2003 Transposable elements: a guide to the perplexed and the novice. With appendices on RNAi, chromatin remodeling and gene tagging. Kluwer Academic Publishers, Dordrecht NL

Ge F, Wang LS, Kim J (2005) The cobweb of life revealed by genome scale estimates of horizontal gene transfer. PLoS Biol 3:e316. doi:10.1371/journal.pbio.0030316

Gil R, Amparo L (2012) Factors behind JUNK DNA in Bacteria. Genes 3:634-650. doi:10.3390/ genes3040634

Gogarten JP, Kibak H, Dittrich P et al (1989) Evolution of the vacuolar H + -ATPase: implications for the origin of eukaryotes. Proc Natl Acad Sci USA 86(17):6661-6665

Goldenfeld N, Woese C (2007) Biology's next revolution. Nature 445:369

Golding G, Gupta RS (1995) Protein based phylogenies support a chimeric origin of the eukaryotic genome. Mol Biol Evol 12:1-6

Goldschmitdt R (1940) The material basis of evolution. Yale University Press, New Haven

Gontier N (2007) Universal symbiogenesis: a genuine alternative to universal selectionist accounts. Symbiosis 44:167-181

Gontier N (2011) Depicting the tree of life: the philosophical and historical roots of evolutionary tree diagrams. Evol Educ Outreach 4(3):515-538

Gray M et al (1989) On the evolutionary origin of the plant mitochondrion and its genome. PNAS 86:2267-2271

Gregory RT 2007 A word about 'Junk DNA'. Evolver Zone Genomicron http://www.genomicron. evolverzone.com/2007/04/word-about-junk-dna/

Gribaldo S, Forterre P, Brochier-Armanet C (2011) Editorial: Archaea and the tree of life. Res Microbiol 162:11-14

Griffith F (1928) The significance of pneumococcal types. J Hyg 27:113-159

Griffiths AJF, Miller JH, Suzuki DT, et al (2000) Bacterial conjugation and bacterial transduction. In: An introduction to genetic analysis, 7th edn. WH Freeman, New York. http://www. ncbi.nlm.nih.gov/books/

Grohmann E, Muth G, Espinosa M (2003) Conjugative plasmid transfer in gram-positive bacteria. Microbiol Mol Biol Reviews 67(2):277-301. doi:10.1128/MMBR.67.2.277-301.2003

Gupta RS, Singh B (1994) Phylogenetic analysis of 70kD heat-shock protein sequences suggest a chimeric origin for the eukaryotic nucleus. Curr Biol 4:1104-1114

Guttman B, Griffiths A, Suzuki D, Cullis T (2002) Genetics. Oneworld, Oxford

Haeckel E (1866) Generelle Morphologie der Organismen: allgemeine Grundzüge der organischen Formen-Wissenschaft, mechanisch begründet durch die von Charles Darwin reformirte Descendenz-Theorie. Fisher, Jena

Hall RM, Stokes HW (2004) Integrons or super integrons? Microbiology 150(Pt 1):3-4. doi:10.1 099/mic.0.26854-0

Handelsman J, Rondon MR, Brady SF, Clardy J, Goodman RM (1998) Molecular biological access to the chemistry of unknown soil microbes: a new frontier for natural products. Chem Biol 5(10):R245-R249. doi:10.1016/S1074-5521(98)90108-9

Hartley RW (1980) Homology between prokaryotic and eukaryotic ribonucleases. J Mol Evol 15(4):355-358

Hayes W (1952) Recombination in Bact. coli K 12: unidirectional transfer of genetic material. Nature 169:118-119

Hayes W (1953) Observations on a transmissible agent determining sexual differentiation in Bacterium coli. J Gen Microbiol 8:72-88

Hebert P et al (2003) Biological identifications through DNA barcodes. Proc R Soc B 270:313321. doi:10.1098/rspb.2002.2218

Heinemann JA, Sprague GF Jr (1989) Bacterial conjugative plasmids mobilize DNA transfer between bacteria and yeast. Nature 340:205-209. doi:10.1038/340205a0 
Hershey AD, Chase M (1952) Independent functions of viral protein and nucleic acid in growth of bacteriophage. J Gen Physiol 36(1):39-56

Hilario E, Gogarten JP (1993) Horizontal transfer of ATPase genes-the tree of life becomes a net of life. Biosystems 31:111-119. doi:10.1016/0303-2647(93)90038-E

Hoelzer MA, Michod RE (1991) DNA repair and the evolution of transformation in Bacillus subtilis. III. Sex with damaged DNA. Genetics 128(2):215-223

Holloway B, Broda P (1996) William Hayes 1918-1994. Hist Rec Aust Sci 11(2):213-228

Hong D-Y, Chen Z-D, Qiu Y-L, Donoghue MJ (2008) Patterns of evolution and the tree of life (a symposium volume). J Syst Evol 46(3)

Hugenholz P, Goebel BM, Pace NR (1998) Impact of culture-independent studies on the emerging phylogenetic view of bacterial diversity. J Bacteriol 180(18):4765-4774

Huxley J (1942) Evolution: the Modern Synthesis. Allen \& Unwin, London

Iwanowski D (1892) Über die Mosaikkrankheit der Tabakspflanze. Bulletin Scientifique publié par l'Académie Impériale des Sciences de Saint-Pétersbourg/Nouvelle Serie III (St. Petersburg) 35:67-70

Iwasaki W, Takagi T (2009) Rapid pathway evolution facilitated by horizontal gene transfers across prokaryotic lineages. PLoS Genet 5(3):e1000402

Jacob F (1955) Transduction of lysogeny in Eschercia coli. Virology 1:207-220

Jacob F, Wollman EL (1958) Les épisomes, elements génétiques ajoutés. Comptes Rendus des Académie des Sciences, Paris 247:154-156

Jacob F, Schaeffer P, Wollman EL (1960) Microbial genetics. Symposium Soc Gen Microbial 10(67):352

Jenner E (1798) An inquiry into the causes and effects of the Vaccinæ, Or Cow-Pox. The Harvard Classics

Johnsborg O, Eldholm V, Håvarstein LS (2007) Natural genetic transformation: prevalence, mechanisms and function. Res Microbiol 158(10):767-778. doi:10.1016/j.resmic.2007.09.004

Jones D, Sneath HA (1970) Genetic transfer and bacterial taxonomy. Bacteriological Rev 34:40431

Karnovsky ML (1981) Metchnikoff in Messina: a century of studies on phagocytosis. N Engl J Med 304(19):1178-1180. doi:10.1056/NEJM198105073041923

Keeling PJ, Palmer JD (2008) Horizontal gene transfer in eukaryotic evolution. Nat Rev Gen 9:605-618. doi:10.1038/nrg2386

Kellis $\mathrm{M}$ et al (2014) Defining functional DNA elements in the human genome. PNAS 111(17):6131-6138. doi:10.1073/pnas.1318948111

Khodosevich K, Lebedev L, Sverdolv E (2002) Endogenous retroviruses and human evolution. Comp Funct Genomics 3:494-498. doi:10.1002/cfg.216

Kidwell MG, Novy JB (1979) Hybrid dysgenesis in Drosophila melanogaster: sterility resulting from gonodal dysgenesis in the P-M system. Genetics 92:1127-1140

Koch R (1876) Untersuchungen ueber Bakterien V. Die Aetiologie der Milzbrand-Krankheit, begruendent auf die Entwicklungsgeschichte des Bacillus Anthracis. Beitr z Biol D Pflanzen 2:277-310

Koch R (1882) Die Aetiologie der Tuberculose. Berliner Klinische Wochenschrift 19:221-230

Kovalevskaia NP (2002) Mobile gene cassettes and DNA integration elements. Mol Biol 36(2):261-267

Kunin V, Goldovsky L, Darzentas N, Ouzounis CA (2005) The net of life: reconstructing the microbial phylogenetic network. Genome Res 15:954-959. doi:10.1101/gr.3666505

Lang AS, Beatty JT (2000) Genetic analysis of a bacterial genetic exchange element: the Gene Transfer Agent of Rhodobacter capsulatus. PNAS 97(2):859-864. doi:10.1073/p nas.97.2.859

Lang AS, Zhaxybayeva O, Beatty TJ (2012) Gene transfer agents: phage-like elements of genetic exchange. Nature Rev Mircobiol 10:472-482

Laveran A (1880) A new parasite found in the blood of malarial patients: parasitic origin of malarial attacks. Bull mem soc med hosp Paris 17:158-164 
Lawton G (2009) Axing Darwin's tree: the tree of life is an iconic image, but it could be time to fell it. New Scientist 201(2692):34-39

Lederberg J (1952) Cell genetics and hereditary symbiosis. Physiol Rev 32(4):403-430

Lederberg J (1955) Recombination mechanisms in bacteria. J Cell Comp Physiol 45(Suppl 2):75

Lederberg J (1956) Genetic transduction. Am Sci 14(3):264-280

Lederberg EM (1981) Plasmid reference center registry of transposon (Tn) allocations through. Gene 16:59-61

Lederberg J (2003) Infectious history. Science 288(5464):27

Lederberg EM, Lederberg J (1953) Genetic studies of lysogenicity in Escherchia coli. Genetics 38:51-64

Lederberg J, Tatum EL (1946) Gene recombination in E coli. Nature 158(4016):558. doi:10.1038/158558a0

Lederberg J, Lederberg EM, Zinder ND, Lively ER (1951) Recombination analysis of bacterial heredity. Cold Spring Harbor Symp Quant Biol 16:413-441

Lederberg J, Cavalli LL, Lederberg EM (1952) Sex compatibility in Escherichia coli. Genetics 37(6):720-730

Lennox ES (1955) Transduction of linked genetic characters of the host by bacteriophage P1. Virology 1:190-206

Lodish H, Berk A, Zipursky SL et al (2000) Molecular cell biology, 4th edn. Freeman, New York

Lopez P, Bapteste E (2009) Molecular phylogeny: reconstructing the forest. Curr Biol 332:171

Lwoff A (1953) Lysogeny. Bact Rev 17:269-337

Lwoff A (1965) Nobel lecture: interaction among virus, cell, and organism. Nobelprizeorg Nobel Media AB http://www.nobelprize.org/nobel_prizes/medicine/ laureates/1965/lwoff-lecture.html

Lwoff A, Gutmann A (1950) Recherches sur un bacillus megatherium lysogène. Ann Inst Pasteur (Paris) 78(6):711-739

Mahillon J, Chandler M (1998) Insertion sequences. Microbiol Mol Biol Rev 62(3):725-774

Mandel M, Higa A (1970) Calcium-dependent bacteriophage DNA infection. J Mol Biol 53(1):159-162. doi:10.1016/0022-2836(70)90051-3

Margulis L (1970) Origin of eukaryotic cells. Yale University Press, New Haven

Margulis L (ed) (1991) Symbiosis as a source of evolutionary innovation: speciation and morphogenesis. The MIT Press, Boston

Margulis L (1998) The symbiotic planet: a new look at evolution. Weidenfeld \& Nicolson, London

Margulis L, Schwartz KV (1997) Five kingdoms: an illustrated guide to the phyla of life on earth. W.H. Freeman \& Company

Marrs BL (1974) Genetic recombination in Rhodopseudomonas capsulata. Proc Natl Acad Sci USA 71:971-973

Martin W (1999) Mosaic bacterial chromosomes: a challenge en route to a tree of genomes. BioEssays 21:99-104

Martinez E, de la Cruz F (1988) Transposon Tn21 encodes a RecA-independent site-specific integration system. Mol Gen Genet 211:320-325

Mashburn-Warren LM, Whiteley M (2006) Special delivery: vesicle trafficking in prokaryotes. Mol Microbiol 61:839-846

Mattick JS (2002) Type IV pili and twitching motility. Annu Rev Microbiol 56(1):289-314. doi:10.1146/annurev.micro.56.012302.160938

Mayer A (1886) Über die Mosaikkrankheit des Tabaks. Die Landwirtschaftliche Versuchsstationen $32: 451-467$

Mazel D (2006) Integrons: agents of bacterial evolution. Nature Rev Microbiol 4:608-620. doi:1 $0.1038 /$ nrmicro 1462

Mazel D, Dychinco B, Webb VA, Davies J (1998) A distinctive class of integron in the Vibrio cholerae genome. Science 280(5363):605-608. doi:10.1126/science.280.5363.605

McClintock B (1941) The stability of broken ends of chromosomes in Zea Mays. Genetics 26(2):234-282 
McClintock B (1950) The origin and behavior of mutable loci in maize. PNAS 36(6):344-355

McClintock B (1953) Induction of instability at selected loci in maize. Genetics 38(6):579-599

Merezhkowsky C (1905) Über natur und ursprung der chromatophoren im pflanzenreiche. Biol Centralbl 25(593-604):689-691

Merezhkowsky C (1910) Theorie der zwei Plasmaarten als Grundlage der Symbiogenese, einer neuen Lehre von der Entstehung der Organismen, Biologisches Centralblatt 30: 278-288, 289-303, 321-347, 353-367

Messing J, Crea R, Seeburg PH (1981) A system for shotgun DNA sequencing. Nucleic Acids Res 9(2):309-321. doi:10.1093/nar/9.2.309

Mindell DP, Villarreal LP (2003) Don't forget about viruses. Science 5:1677

Mitsuhashi S, Harada K, Hashimoto H, Egawa R (1961) On the drug-resistance of enteric bacteria. Jpn J Exp Med 31:47-52

Moran NA, Jarvik T (2010) Lateral transfer of genes from fungi underlies carotenoid production in Aphids. Science 328:624-627

Morange M (2000) A history of molecular biology. Harvard University Press, Cambridge (New Edited edition)

Morgan GJ (1998) Emile Zuckerkandl, Linus Pauling, and the molecular evolutionary clock, 1959-1965. J Hist Biol 31(2):155-178. doi:10.1023/A:1004394418084

Morse ML, Lederberg EM, Lederberg J (1956) Transduction in Eschercia coli K-12. Genetics 41:142-156

Nelson PN, Hooley P, Molecular Immunology Research Group (2004) Human endogenous retroviruses: transposable elements with potential? Clin Exp Immunol 138(1):1-9 doi:10.1111/j.1365-2249.2004.02592.x

Neufeld F (1902) Über die agglutination der pneumokokken und über die theorieen der agglutination. Z Hyg Infektionskr 40:54-72

Neufeld F, Händel L (1910) Weitere Untersuchungen über Pneumokokken Heilsera. III Mitteilung. Über Vorkommen und Bedeutung atypischer Varietäten des Pneumokokkus. Arbeit a.d. Kaiserlichen Gesundheitsamte 34:293-304

O'Malley M, Martin W, Dupré J (2010) The tree of life: introduction to an evolutionary debate. Biol Philos 25(4):441-453

Ochia K, Yamanaka T, Kimura K, Sawada O (1959) Inheritance of drug resistance (and its transfer) between Shigella strains and between Shigella and E. coli strains. Nihon Iji Shimpo 1861:34

Ohno S (1972) So much junk DNA in our genome. In: Smith HH (ed) Evolution of genetic systems. Gordon and Breach, New York, pp 366-370

Ohshima K, Okada N (2005) SINEs and LINEs: symbionts of eukaryotic genomes with a common tail. Cytogenet Genome Res 110(1-4):475-490. doi:10.1159/000084981

O'Malley MA, Koonin EV (2011) How stands the tree of life a century and a half after the origin? Biology Direct 6:32

Palmer JD, Soltis DE, Chase MW (2004) The plant tree of life: an overview of some points of view. Am J Bot 91(10):1437-1445

Pardee AB, Jacob F, Monod J (1959) The genetic control and cytoplasmic expression of inducibility in the synthesis of beta-galactosidase by E. coli. J Mol Biol 1:165-178

Pasteur L (1880) De l'attenuation du virus cholera des poules. CR Acad Sci 91:673-680

Pettersson E, Lundeberg J, Ahmadian A (2009) Generations of sequencing technologies. Genomics 93(2):105-111. doi:10.1016/j.ygeno.2008.10.003

Proft T, Baker EN (2009) Pili in gram-negative and gram-positive bacteria-structure, assembly and their role in disease. Cell Mol Life Sci 66(4):613-635. doi:10.1007/s00018-008-8477-4

Ragan MA, McInerney JO, Lake J (2009) The network of life: genome beginnings and evolution. Phil Trans R Soc B 364(1527):2169-2175

Redfield R, Schrag M, Dead A (1997) The evolution of bacterial transformation: sex with poor relations. Genetics 146(1):27-38

Reinheimer H (1915) Symbiogenesis: the universal law of progressive evolution. Knapp, Drewett and Sons Ltd, Westminster 
Rivera MC, Lake JA (2004) The ring of life provides evidence for a genome fusion origin of eukaryotes. Nature 431(2005):152-155. doi:10.1038/nature02848

Ryan F (2004) Human endogenous retroviruses in health and disease: a symbiotic perspective. J Roy Soc Med 97:560-565

Ryan F (2009) Virolution. Harper Collins, London

Sakai T, Iseki S (1954) Transduction of flagellar antigen in Salmonella E group. Gunma Jour Med Sco 3:195-199

Salmon DE, Smith T (1886) On a new method of producing immunity from contagious diseases. Proc Biol Soc 3:29-33

San Mauro D, Agorreta A (2010) Molecular systematics: a synthesis of the common methods and the state of knowledge. Cell Mol Biol Lett 15(2):311-341. doi:10.2478/s11658-010-0010-8

Sanger F, Coulson AR (1975) A rapid method for determining sequences in DNA by primed synthesis with DNA polymerase. J Mol Biol 94(3):441-448. doi:10.1016/0022-2836(75)90213-2

Sapp J (1994) Evolution by association: a history of symbiosis. Oxford University Press, New York

Sapp J (2003) Genesis: the evolution of biology. Oxford University Press, New York

Sapp J (2009) The new foundations of evolution: on the tree of life. Oxford Univ. Press, New York

Schuster S (2008) Next-generation sequencing transforms today's biology. Nat Methods 5(1):16-8 doi:10.1038/nmeth1156 (PMID 18165802)

Scott JR, Zähner D (2006) Pili with strong attachments: gram-positive bacteria do it differently. Mol Microbiol 62(2):320-330

Serrelli E, Gontier N (eds) (2015) Macroevolution: explanation, interpretation and evidence. Springer, Dordrecht

Shapiro JA (1979) Molecular model for the transposition and replication of bacteriophage $M u$ and other transposable elements. Proc Natl Acad Sci USA 76(4):1933-1937. doi:10.1073/p nas.76.4.1933

Shapiro JA (ed) (1983) Mobile genetic elements. Academic Press, Waltham

Shine J, Czernilofsky AP, Friedrich R, Bishop JM, Goodman HM (1977) Nucleotide sequence at the $5^{\prime}$ terminus of the avian sarcoma virus genome. Proc Natl Acad Sci USA 74(4):14731477. doi:10.1073/pnas.74.4.1473

Singer MF (1982) SINEs and LINEs: highly repeated short and long interspersed sequences in mammalian genomes. Cell 28(3):433-434. doi:10.1016/0092-8674(82)90194-5

Sisco KL, Smith HO (1979) Sequence-specific DNA uptake in Haemophilus transformation. PNAS 76(2):972-976. doi:10.1073/pnas.76.2.972

Spradling AC, Rubin GM (1982) Transposition of cloned P elements into Drosophila germ line chromosomes. Science 218(4570):341-347. doi:10.1126/science.6289435

Staden R (1979) A strategy of DNA sequencing employing computer programs. Nucleic Acids Res 6(7):2601-2610. doi:10.1093/nar/6.7.2601

Stanto TB (2007) Prophage-like gene transfer agents-novel mechanisms of gene exchange for Methanococcus, Desulfovibrio, Brachyspira, and Rhodobacter species. Anaerobe 13(2):43-49

Stokes HW, Hall RM (1989) A novel family of potentially mobile DNA elements encoding sitespecific gene-integration functions: integrons. Mol Microbiol 3:1669-1683

Summers WC (2006) Phage and the early development of molecular biology. In: Bacteriophages The (ed) Calendar R. Oxford Univ Press, New York

Syvänen M (1984a) Conserved regions in mammalian ß-globins: could they arise by cross-species gene exchange? J Theor Biol 107:685-696

Syvänen M (1984b) The evolutionary implications of mobile genetic elements. Annu Rev Genet 18:271-293

Syvänen M (1985) Cross-species gene transfer, implications for a new theory of evolution. J Theor Biol 112(2):333-343. doi:10.1016/S0022-5193(85)80291-5 
Syvänen M (1986) Cross-species gene transfer: a major factor in evolution? Trends Genetic 4:1-4

Syvanen M (1987) Molecular clocks and evolutionary relationships: possible distortions due to horizontal gene flow. J Mol Evol 26(1-2):16-23

Syvanen M, Kado CI (eds) (1998) Horizontal gene transfer. Chapman \& Hall, London

Tan SY, Dee MK (2009) Elie Metchnikoff (1845-1916): discoverer of phagocytosis. Signapore Med L 50(5):456

Tauber AI (2003) Metchnikoff and the phagocytosis theory. Nat Rev Mol Cell Biol 4:897-901

Temin HM (1980) Origin of retroviruses from cellular movable genetic elements. Cell 21:599-600

The ENCODE Project Consortium et al (2012) An integrated encyclopedia of DNA elements in the human genome. Nature 489(7414):57-74. doi:10.1038/nature11247

Thomas CM (2000) Horizontal gene pool: bacterial plasmids and gene spread. CRC Press, Boca Raton

Trevors JT, Barkay T, Bourquin AW (1987) Gene transfer among bacteria in soil and aquatic environments: a review. Canad J Microbiol 33(3):191-198

Twort F (1915) An investigation on the nature of ultra-microscopic viruses. Lancet 2:1241-1243

Van Beneden PJ (1873) Un mot sur la vie sociale des animaux inférieurs. Bull Acad R Belgique série 2(36):779-796

Van Beneden PJ (1875) Les comensaux et les parasites dans le règne animal. Biblio Sci. Int, Paris

Villareal LP, Defilipps V (2000) A hypothesis for DNA viruses as the origin of eukaryotic replication proteins. J Virol 74(15):7079-7084

Villarreal LP, Witzany G (2010) Viruses are essential agents within the roots and stem of the tree of life. J Theor Biol 262(4):698-710

Von Faber FC (1912) Das erbliche zusammenleben von bacterien und tropischen pflanzen. Jahrb Wiss Bot 51:285-375

Wallin IE (1927) Symbionticism and the origin of species. Williams and Wilkins company, Baltimore

Watanabe T (1971) The problems of drug-resistant pathogenic bacteria: the origin of $\mathrm{R}$ factors. Ann NY Acad Sci 182:126-140

Weickert MJ, Adhya S (1993) The galactose regulon of Escherichia coli. Mol Microbio 10(2):245-251

Weiner AM (2002) SINEs ans LINEs: the art of biting the hand that feeds you. Curr Opin Cell Biol 14:343-350

Weismann A (1885) Die Continuität des Keimplasma's als Grundlage einer Theorie der Vererbung. Fischer, Jena

Whittaker RH, Margulis L (1978) Protist classification and the kingdoms of organisms. Biosystems 10:3-18

Wicker T, Sabot F, Hua-Van A et al (2007) A unified classification system for eukaryotic transposable elements. Nat Rev Genet 8(12):973-982. doi:10.1038/nrg2165

Williams D, Fournier GP, Lapierre P et al (2011) A rooted net of life. Biology Direct 6:45

Woese CR (1967) The genetic code: the molecular basis for genetic expression. Harper \& Row

Woese CR (1998) The universal ancestor. PNAS 95(12):6854-6859

Woese CR, Fox GE (1977) Phylogenetic structure of the prokaryotic domain: the primary kingdoms. PNAS 74(11):5088-5090. doi:10.1073/pnas.74.11.5088

Woese CR, Kandler O, Wheelis ML (1990) Towards a natural system of organisms: proposal for the domains Archaea, Bacteria, and Eucarya. Proc Natl Acad Sci USA 87:4576-4579. doi: 10.1073/pnas.87.12.4576

Wolf K, Delgiudice L (1987) Horizontal gene transfer between mitochondrial genomes. Endocytobiosis Cell Res 4(2):103-120

Wollman EL, Jacob F (1955) Sur le mécanisme du transfer de matériel génétique au cours de la recombination chez E. coli K12. Compt Rend Acad Sci 240:2449-2451 
Yen HC, Hu NT, Marrs BL (1979) Characterization of the gene transfer agent made by an overproducer mutant of Rhodopseudomonas capsulata. J Mol Biol 131:157-168

Zhang Q, Arbuckle J, Wessler SR (2000) Recent, extensive, and preferential insertion of members of the miniature inverted-repeat transposable element family Heartbreaker into genic regions of maize. Proc Natl Acad Sci USA 97:1160-1165

Zhaxybayeva O, Doolittle WF (2011) Lateral gene transfer. Curr Biol 21(7):R242-R246

Zinder ND (1955) Bacterial transduction. J Comp Physiol 45(Suppl 2):23-49

Zinder ND (1992) Forty years ago: the discovery of bacterial transduction. Genetics 132(2):291-294

Zinder ND, Lederberg J (1952) Genetic exchange in Salmonella. J Bact 64:679-699

Zuckerkandl E, Pauling L (1962) Molecular disease, evolution, and genic heterogeneity. In: Kasha M, Pullman B (eds) Horizons in biochemistry. Academic Press, New York, pp 189-225

Zuckerkandl E, Pauling L (1965a) Evolutionary divergence and convergence in proteins. In: Bryson V, Vogel HJ (eds) Evolving genes and proteins. Academic Press, New York, pp 97-166

Zuckerkandl E, Pauling L (1965b) Molecules as documents of evolutionary history. J Theor Biol $8(2): 357-366$ 